\title{
Sustainability and design assessment of rural hybrid microgrids in Venezuela
}

\author{
A. López-González ${ }^{1,2,3, *}$, B. Domenech ${ }^{1}$, L. Ferrer-Martí ${ }^{1}$ \\ ${ }^{1}$ Institute of Industrial and Control Engineering, Universitat Politècnica de Catalunya - BarcelonaTech (Spain) \\ ${ }^{2}$ Institute of Sustainability, Universitat Politècnica de Catalunya - BarcelonaTech (Spain) \\ ${ }^{3}$ Socioeconomic Center of Petroleum and Alternative Energies, Universidad del Zulia (Venezuela) \\ Contact (*): a.lopez@upc.edu ; (+34) 934.016.579
}

\begin{abstract}
Nowadays, 1.2 billion people lack access to electricity, mainly in rural areas of developing countries. In particular, 22 million people do not have electricity in Latin America and many governments are developing rural electrification programs to deal with this situation. Off-grid hybrid microgrids based on renewable energy are an efficient option for providing dispersed rural populations with access to electricity. However, microgrids are still a minority option, as governments of developing countries generally consider them expensive and not effective. In this context, the evaluation of projects based on hybrid microgrids is required in order to improve the knowledge about these technologies. In this paper, 13 microgrid projects in north-western Venezuela are presented and their environmental, technical, socioeconomic and institutional dimensions of sustainability are evaluated. For this purpose, an evaluation methodology based on some ad hoc criteria is developed, assessed by means of technical visits, semi-structured interviews and 106 surveys of technical operators and beneficiaries. The results show that microgrids can satisfy the energy needs of the population, while promoting technological change towards the use of more sustainable technologies. In addition, the key aspects for strengthening projects' sustainability are highlighted.

Keywords: hybrid microgrids; rural electrification; sustainability assessment; wind-PV-diesel-battery, Venezuela
\end{abstract}

\section{Introduction}

Nowadays, 1.2 billion people lack access to electricity in the poorer rural areas of developing countries. In Latin America, 22 million people do not have electricity [1]. In these regions, given the dispersion of houses and the long distances to urban centres, the national electricity grid extension or the fuel supply for diesel gensets are not economically profitable [2]. Consequently, off-grid systems based on renewable energy technologies (RET) become an effective strategy for electricity access and poverty reduction, while reducing greenhouse gas emissions [3]. Indeed, the use of renewable energy has progressively increased, and 300 million people obtained access to electricity by means of off-grid RET-based systems from 2007 to 2016 [4]. Solar photovoltaic (PV) panels are the most common option, representing almost 50\% of the total RETs for rural electrification [5], mainly through solar home systems (SHS) [6]. However, according to Hosseinalizadeh et al. [7] and Kaldellis et al. [8], wind energy can be also profitable and appropriate in regions having wind or wind and solar resources.

Off-grid systems may provide electricity through stand-alone home systems or microgrids (generators supplying electricity to several consumption points via a small network) [3]. Although stand-alone home systems are widely used, microgrids can be more profitable and reliable according to the distribution of houses [9]. When relying on more than one renewable energy source (RES), for example, wind and solar, the hybrid microgrid concept is commonly used, and both RES lead to a more reliable supply [10]. In fact, hybrid wind-PV microgrids can provide endusers with an even better service quality than that of conventional fuel-based technologies [3]. However, the long-term sustainability of hybrid microgrid projects is still an issue [11].

In order to improve sustainability [12], key aspects from project failures or successes should be identified and the quantity and quality of information provided to decision-makers must be increased [13]. Despite the large amount of rural electrification projects implemented in developing countries, very few empirical evaluations analysing the factors that influence the 
success and sustainability of small-scale projects have been published [14]. There are very few empirical evaluations of community RET-based projects assessed in situ several years after their installation [15].

The three basic dimensions of sustainability were established in 1987 [16]: economic, social and environmental [17]. Later, Ilskog et al. [18] maintained those three dimensions, calling the social aspect socio-ethical and adding two more: technical and institutional. Most studies have a clear focus on technical and institutional aspects, such as mentioned by Yadoo [19] and Schillebeeckx [20], while fewer consider the relevance of social and economic factors for the sustainability assessment [17]. A single socioeconomic dimension is considered in this paper, as the economic and social dimensions are related. Therefore, 4 dimensions for the sustainability assessment are proposed: environmental, technical, socioeconomic and institutional. The four dimensions are evaluated through some ad hoc specific criteria which can be assessed by end-user surveys, technical visits, simulations or other adequate tools. The definition of the criteria was made together with technicians from the Electricity Ministry of Venezuela. The proposed criteria are sufficiently robust and flexible to be easily used in other contexts, regions and countries [18]. Therefore, the four dimensions are valid for the evaluation of rural electrification projects in any context, only adapting the way that each criterion is assessed to accord with the specific conditions of each case study.

In this context, the main contribution of this paper is the evaluation of 13 hybrid microgrids in Venezuela, implemented within the "Sembrando Luz" ("Sowing Light") program [21]. For this purpose, a comprehensive evaluation methodology is developed, which may be applicable to programs and/or specific RET-based rural electrification projects in developing countries. The methodology considers the 4 aforementioned sustainability evaluation dimensions: environmental, technical, socioeconomic and institutional. The information required for the evaluation is gathered from surveys of end-users, interviews with technical and community leaders, historical record data and simulations using HOMER. Results show the key elements for the long term sustainability of the projects, from the microgrid design to their implementation, and are useful for the next 149 hybrid microgrids the Venezuelan government has planned to install [22].

The remainder of the paper is organised as follows. In Section 2, the technical aspects, the design process and the generation technologies used in the microgrid projects in Venezuela are described. Section 3 presents the evaluation methodology, while Section 4 explains the results obtained for each sustainability dimension, based on the criteria defined. In Section 5, the results for the 4 dimensions are discussed. Finally, the main conclusions are summarised in Section 6.

\section{Design description of hybrid microgrids in Venezuela}

The design and implementation of hybrid microgrids is one of the electrification strategies within the "Sowing Light" program, developed by the Venezuelan government [21]. To date, 18 microgrids have been installed; the first 13 in northwest Venezuela, 4 in communities in Falcón state and 9 in Zulia state (Figure 1). In Falcón the communities are composed of Creoles [23] whereas in Zulia the population belongs to the Wayuú ethnic group [24]. The indigenous population in Venezuela are a small minority, usually located in dispersed rural settlements with low access to education, health and information services, which influences their socioeconomic development [25].

In the following sections, the sizing and standardisation of hybrid microgrids in north-western Venezuela is described (Section 2.1), as well as the wind and solar generation technologies 
(Section 2.2), the diesel backup and the battery storage (Section 2.3). Finally, the microgrid structure and control strategy (Section 2.4) and the management model (Section 2.5) are detailed.

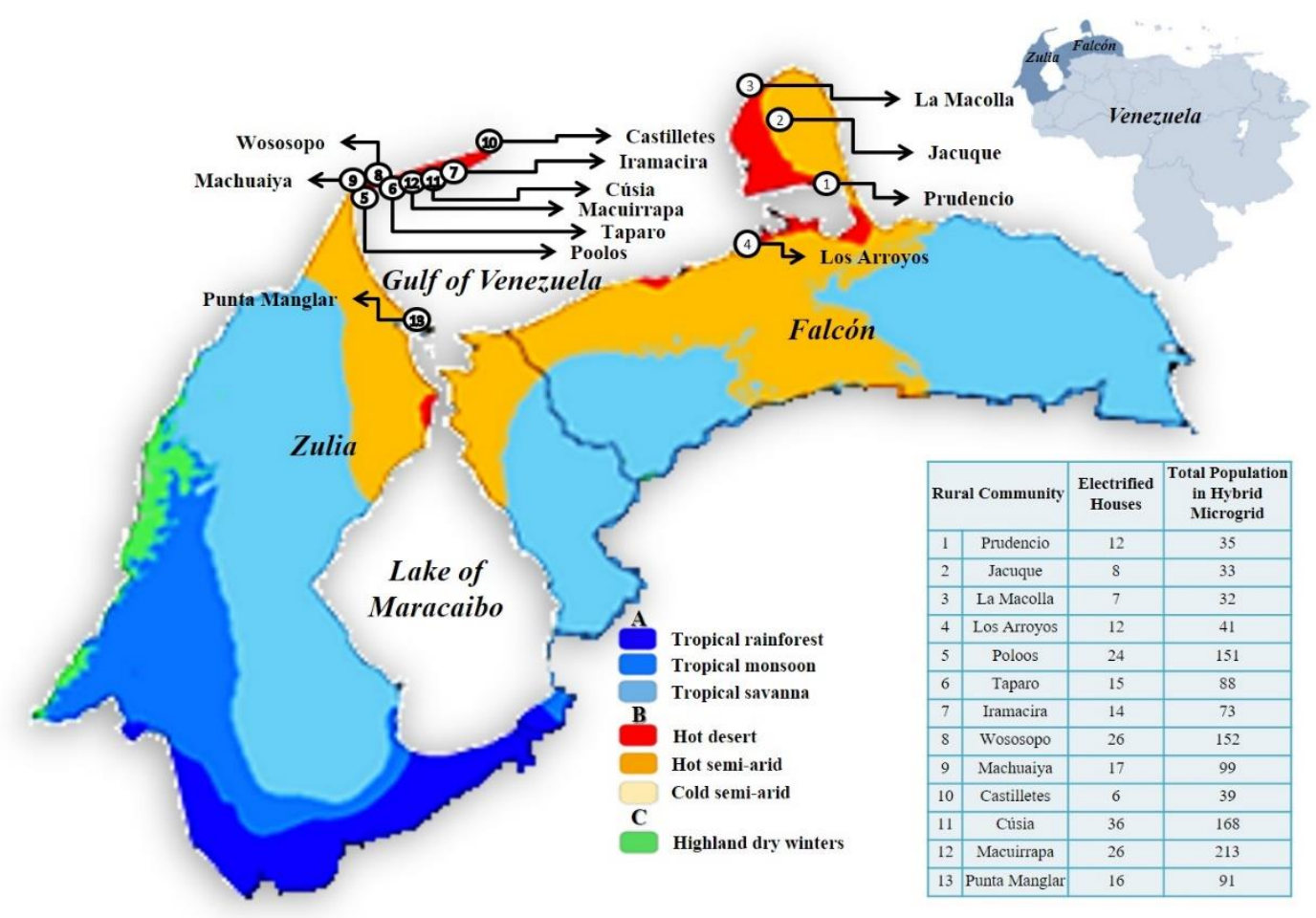

Figure 1. Hybrid microgrid locations in north-western Venezuela, within the Köppen climate map [26]

\subsection{Hybrid microgrid sizing and design standardisation}

The estimation of the average daily consumption was carried out by Fundelec (Ministry of Electric Energy of Venezuela). The estimation was based on historical data obtained during the national censuses carried out by the National Institute for Statistics of Venezuela (INE), in previously electrified rural houses. Moreover, Fundelec carried out surveys in rural areas to be electrified in order to profile the houses and inhabitants. Thus, a typical list of house appliances and their use was generated (Table 1). In this way, Fundelec estimated an energy demand of $2 \mathrm{kWh} /$ day and a peak power of $0.45 \mathrm{~kW}(\approx 0.6 \mathrm{kVA})$ [27]. These values represent an approximate $730 \mathrm{kWh} /$ year per home (182-122 kWh/year per capita, depending on the number of residents) [27]. These estimations are consistent with those predicted by Rojas-Zerpa et al. [28], and exceed the minimum threshold established by the United Nations (100 kWh/year per capita) [14]. Moreover, a demand of $3.8 \mathrm{kWh} /$ day was considered for schools and health centres, and $5.1 \mathrm{kWh} /$ day for churches [22].

Next, a socio-demographic evaluation of the distribution of non-electrified rural settlements in Venezuela was carried out, based on the databases of the National Institute for Statistics (INE) [25]. In this regard, INE compiled data about electrified and non-electrified rural settlements, and the number of houses in them. From these data, an estimated $96.23 \%$ of non-electrified rural houses are grouped in settlements of 40 or fewer houses (Figure 2). Among them, 72.81\% correspond to settlements of more than 3 houses, to be electrified through hybrid microgrids. The results show the high dispersion of the houses with no electricity in Venezuela and that most of these houses are inhabited by the indigenous population. Indeed, the indigenous population in rural Venezuela has historically been established in scattered settlements, living in small shacks ("ranchos"), as a consequence of their semi-nomadic lifestyle [29]. On average there are 6 people per house, with very small energy needs, in accordance with their traditional customs and habits. 
Table 1. Daily average consumption estimation procedure is based on Fundelec surveys on rural houses all over Venezuela and result is a $2 \mathbf{k W h} / \mathbf{d}$ [27]

\begin{tabular}{|c|c|c|c|}
\hline House appliances & Quantity & $\begin{array}{c}\text { Daily use } \\
\text { (Hours) }\end{array}$ & $\begin{array}{c}\text { Average daily } \\
\text { consumption (Wh) }\end{array}$ \\
\hline T.V & 1 & 5 & 400 \\
\hline Fluorescent light bulbs & 5 & 5 & 275 \\
\hline Electronic devices & 1 & 5 & 125 \\
\hline Freezer & 1 & 24 & 1200 \\
\hline \multicolumn{3}{|c|}{ Total average daily consumption (Wh) } & $2000(2 \mathrm{kWh})$ \\
\hline
\end{tabular}

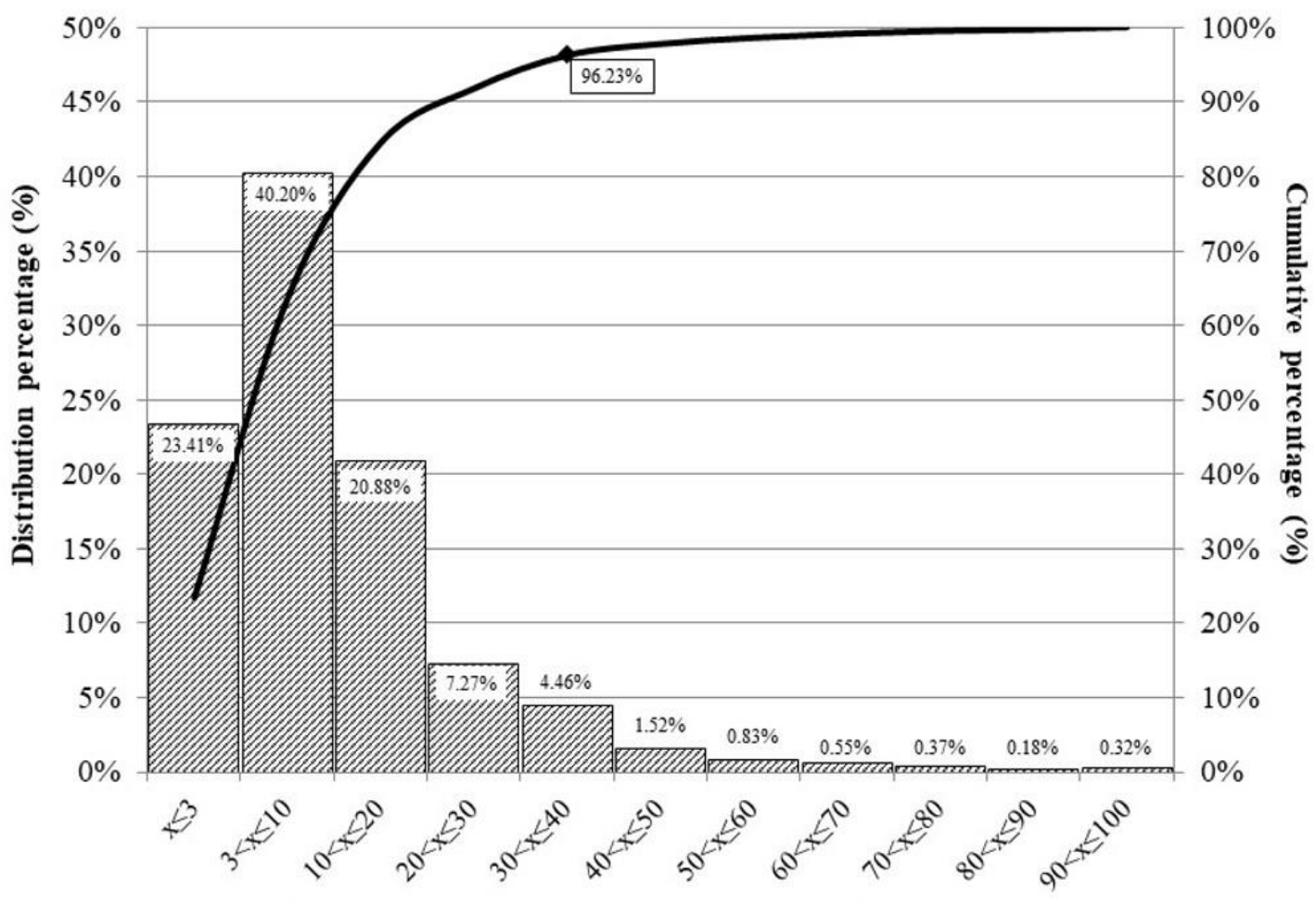

Clustering of unelectrified houses per rural settlements

Figure 2. Clustering of houses in non-electrified rural settlements of Venezuela

The design of the hybrid microgrids was developed by Fundelec using HOMER software [30]. In the electrified communities there are no rivers nor other available Renewable Energy Sources (RES) except solar and wind. In some communities, the wind speed reaches up to 8-10 $\mathrm{m} / \mathrm{s}$ [31], which is the highest wind category defined by the National Renewable Energy Laboratory [32]. The solar potential is also high, ranging from 5.5 to $6.7 \mathrm{kWh} / \mathrm{m}^{2} /$ day in the electrified communities of Zulia and exceeding $6.7 \mathrm{kWh} / \mathrm{m}^{2} /$ day in those of Falcón [27], with a very low variation throughout the year [33]. Therefore, Solar-Wind Hybrid Microgrids were the standard microgrid design considered, according to different load levels, for all the planned projects in both states. Taking into account the average daily consumption of common rural houses, the hybrid wind-PV-diesel-battery microgrids were expected to supply the demand of houses and community infrastructures such as schools, churches and health centres. The microgrids were designed in configurations for up to 10, 20, 30 and 40 houses, called SH-10, SH-20, SH-30 and SH-40, respectively (Table 2). The maximum capacity shortage was defined according to rural distribution network data from the Electricity Ministry of Venezuela [22]. Table 2 also summarises the wind-PV generation equipment and the backup and storage systems used in each configuration and detailed in the following sections [21]. 
Table 2. Hybrid microgrid configurations in Venezuela according to the load [21]

\begin{tabular}{|c|c|c|c|c|c|c|c|}
\hline \multirow{2}{*}{$\begin{array}{c}\text { Hybrid } \\
\text { Microgrid } \\
\text { configuration }\end{array}$} & \multicolumn{2}{|c|}{$\begin{array}{c}\text { Solar PV } \\
\text { generation }\end{array}$} & \multicolumn{2}{c|}{$\begin{array}{c}\text { Small wind } \\
\text { generation }\end{array}$} & \multicolumn{2}{c|}{ Battery storage } & $\begin{array}{c}\text { Diesel } \\
\text { backup }\end{array}$ \\
\cline { 2 - 7 } & Quantity & $\begin{array}{c}\text { Total } \\
\text { capacity }\end{array}$ & Quantity & $\begin{array}{c}\text { Total } \\
\text { capacity }\end{array}$ & Quantity & $\begin{array}{c}\text { Total } \\
\text { capacity }\end{array}$ & $\begin{array}{c}\text { Total } \\
\text { capacity }\end{array}$ \\
\hline $\begin{array}{c}\text { 10 houses } \\
\text { (SH-10) }\end{array}$ & $\begin{array}{c}20 \mathrm{x} \\
150 \mathrm{~W}\end{array}$ & $3 \mathrm{~kW}$ & $1 \times 3 \mathrm{~kW}$ & $3 \mathrm{~kW}$ & $\begin{array}{c}24 \mathrm{x} \\
1,080 \mathrm{Ah}\end{array}$ & $25,920 \mathrm{Ah}$ & $9 \mathrm{~kW}$ \\
\hline $\begin{array}{c}\mathbf{2 0} \text { houses } \\
\text { (SH-20) }\end{array}$ & $\begin{array}{c}36 \mathrm{x} \\
160 \mathrm{~W}\end{array}$ & $5.76 \mathrm{~kW}$ & $1 \times 6 \mathrm{~kW}$ & $6 \mathrm{~kW}$ & $\begin{array}{c}48 \times \\
800 \mathrm{Ah}\end{array}$ & $38,400 \mathrm{Ah}$ & $14 \mathrm{~kW}$ \\
\hline $\begin{array}{c}\mathbf{3 0} \text { houses } \\
\text { (SH-30) }\end{array}$ & $\begin{array}{c}56 \mathrm{x} \\
150 \mathrm{~W}\end{array}$ & $8.4 \mathrm{~kW}$ & $1 \times 3 \mathrm{~kW}$ & $9 \mathrm{~kW}$ & $\begin{array}{c}48 \mathrm{x} \\
1,200 \mathrm{Ah}\end{array}$ & $57,600 \mathrm{Ah}$ & $19 \mathrm{~kW}$ \\
\hline $\begin{array}{c}\mathbf{4 0} \text { houses } \\
\text { (SH-40) }\end{array}$ & $\begin{array}{c}72 \mathrm{x} \\
150 \mathrm{~W}\end{array}$ & $10.8 \mathrm{~kW}$ & $2 \times 6 \mathrm{~kW}$ & $12 \mathrm{~kW}$ & $\begin{array}{c}96 \mathrm{x} \\
800 \mathrm{Ah}\end{array}$ & $76,800 \mathrm{Ah}$ & $23 \mathrm{~kW}$ \\
\hline
\end{tabular}

\subsection{Small wind and solar PV technologies}

Rural communities in Zulia and Falcón are located in territories where the average annual temperature exceeds $30{ }^{\circ} \mathrm{C}$ [34], ranging from $28^{\circ}$ to $34^{\circ} \mathrm{C}$ [24]. According to Köppen climate classification [26], Zulia and Falcón have a hot semi-arid $(B s h)$ and hot desert $(B w h)$ climate, respectively, characterized by strong solar radiation, continuous trade winds, a dry year-round climate, and high and constant temperatures. These two states were the first in the country to benefit from hybrid wind-PV microgrids for the electrification of rural communities within the "Sowing Light" program [21]. Regarding the wind technology, permanent magnet synchronous generator wind turbines were used. The turbines have a 4-m diameter with 2 and 3 blades, and capacities of 3 and $6 \mathrm{~kW}$ respectively. The direct current (DC) output, after the rectification phase, is 24 and $48 \mathrm{~V}$, respectively. The technical performance of Small Wind Turbines (SWT) was measured and certified prior to installation and the power curve is shown in Figure 3 [35]. Under the climate conditions in north-western Venezuela, wind turbines have an estimated lifetime of 15 years, assuming the appropriate preventive maintenance is carried out, which represents an average annual cost of $33 \$ / \mathrm{kW}$ [36]. Since 2012, these turbines are manufactured in Venezuela by a national public company, which has significantly reduced the hybrid microgrid costs [37].
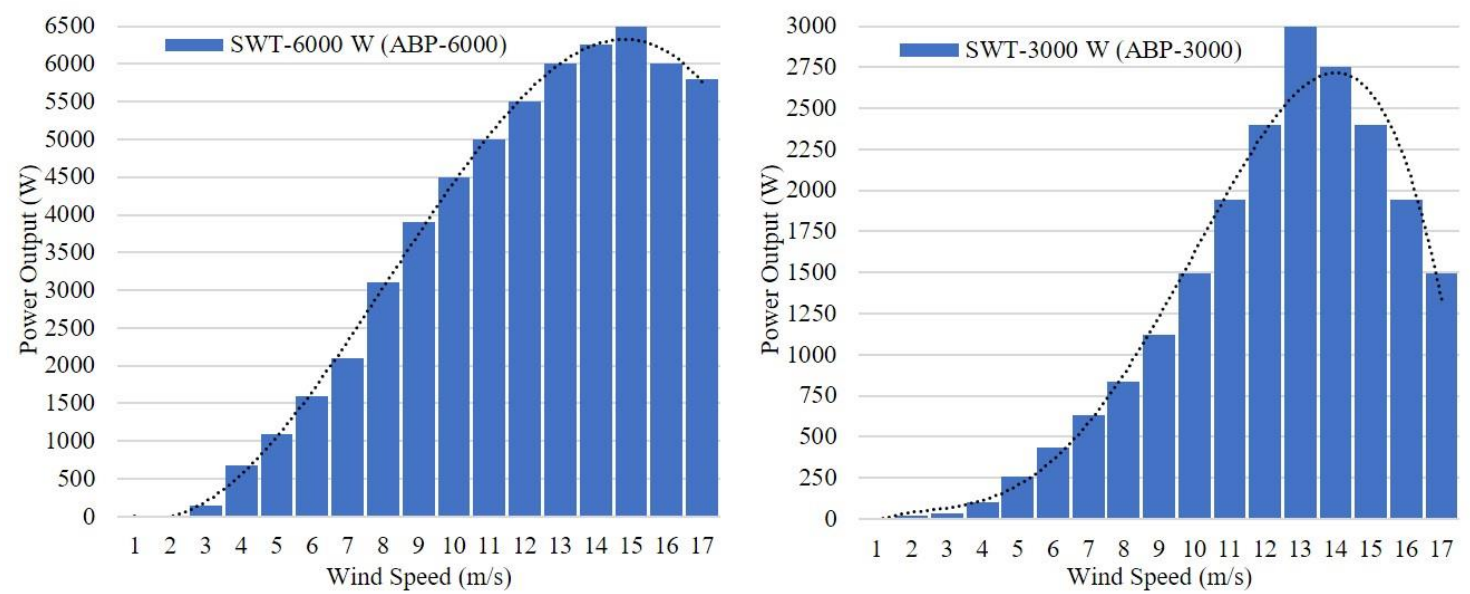

Figure 3. Power curve of $6000 \mathrm{~W}$ and $3000 \mathrm{~W}$ small wind turbines installed in rural hybrid microgrids in north-western Venezuela

Regarding the solar PV technology, 150 and $160 \mathrm{Wp}$ capacity panels were used, made from textured polycrystalline silicon with an anti-reflective layer. Given that the working temperature of the module can exceed $45^{\circ} \mathrm{C}$, the losses are equivalent to a power reduction of around $10 \%$. Also, a production loss of $20 \%$ is estimated when environmental factors such as dust, shade or the climate are considered [38]. Throughout the design phase a working lifetime of 25 years was assumed, with the adequate preventive maintenance being applied, leading to a yearly operation and maintenance (O\&M) cost of $10 \$ / \mathrm{kW}$ [36]. Table 2 shows the PV panels installed, depending 
on the number of houses focussed. The panels have been manufactured in Venezuela since 2012, by the same company that produces the wind turbines [37].

\subsection{Diesel backup and battery storage technologies}

The hybrid microgrids have been designed with a diesel generator backup and a set of batteries for energy storage. This equipment was designed according to the energy resources available, based on the regional databases of north-western Venezuela, while aiming to balance the fluctuations in generated power [10]. Both systems avoid the need for an expensive oversizing of wind-PV generators [39]. In addition, batteries store the excess electricity for later use during periods of lower energy resource availability. In this way, the operating hours of the diesel backup are minimised and the fraction of renewable energy generation increases [40].

Regarding the storage system, conventional lead-acid batteries with electrolytic liquid were used, since they were the cheapest option. This is a robust technology that also has high operational security, so it has been commonly used in solar and small wind applications worldwide [40]. Table 2 shows the batteries installed, depending on the number of houses focussed. Energy losses from the conversion as well as the battery state of charge (SOC) during load and discharge were considered during the microgrid design [41].

Previous investigations recommend, through prolonged experimentations, a SOC above 50\% as being ideal for lead-acid batteries; and a well-controlled hybrid system should keep such SOC during at least $90 \%$ of the cases [42]. Moreover, lead-acid batteries used for RET applications are generally limited to a minimum SOC of $80 \%$ [43]. If this value is exceeded, the battery suffers from over-discharge, which may result in permanent damage of the battery, shortening its lifetime. Therefore, these systems were designed in order to keep the battery State of Charge (SOC) at over $80 \%$. Additionally, the storage system size was calculated according to a microgrid selfsufficiency of 2 days, taking into account the complementarity of the generation systems [44]. The self-sufficiency period is calculated according to full charge consumption ( $2 \mathrm{kWh} /$ day per house) [27]. The estimated lifetime and yearly O\&M cost were 20 years and $2 \$ /$ battery, respectively [36].

Regarding the backup system, 9, 14, 19 and $23 \mathrm{~kW}$ diesel generators were used for the 10, 20, 30 and 40 house configurations, respectively (Table 2). These generators were sized to supply the full load of the microgrid during failures in RET generation and to simultaneously charge the battery set. Hence, the energy provided by diesel generators was not expected to exceed $10 \%$ of the annual energy of the microgrid when operating under normal conditions [45]. The O\&M costs were defined according to the operating hours: $2 \$ / \mathrm{h}$, including fuel costs, while the expected lifetime was $15,000 \mathrm{~h}$ with appropriate maintenance tasks, i.e. around 10-15 years [36]. The optimisation of the hybrid microgrids was reached by minimising the excess energy, while maximising the fraction of renewable energy generation and reducing the supply from the diesel generator to less than $10 \%$. Under such assumptions, the cost per produced $\mathrm{kWh}$ is significantly reduced. Table 3 summarizes all the technologies used in the rural hybrid microgrids projects and configurations according to number of houses, all over Venezuela.

\subsection{Microgrid architecture and control strategy}

All the configurations for the designed hybrid microgrids use mixed AC/DC architectures, since they allow direct connection between the generation systems depending on the output power. In this regard, the diesel backup is connected to an AC bus, while there are separate DC buses for the RET-based generators (PV modules and wind turbines) and the battery storage system [45]. Thus, these microgrids have a mixed parallel architecture with bidirectional power inverters, including a master and slaves, installed between the two buses. The master is responsible for energy 
management, controlling the energy production, the battery charge and the diesel turn on/off [36]. The slaves have a similar function but under the control of the master converter [46]. Using this architecture, significant control benefits can be achieved [47]. Figure 4 shows a layout of this mixed AC/DC architecture.

Table 3. Renewable energy, storage and backup technologies used for the design and implementation of rural hybrid microgrids in Venezuela

\begin{tabular}{|c|c|c|c|}
\hline Solar PV generation & Small wind generation & Battery Storage & Diesel Backup \\
\hline $\begin{array}{l}\text { Two types are used } \\
\text { Maximum Power } 150 \pm 5 \% \text {; } \\
\text { Short Circuit Current (Isc)=8,9 } \\
\text { A; Open Circuit Voltage } \\
\text { (Voc)=21,6 V; Max. Power } \\
\text { Current= 8,7 A, Max Power } \\
\text { Voltage: } 17,3 \text { V. } \\
\text { Maximum Power } 160 \pm 5 \% \text {; } \\
\text { Short Circuit Current (Isc)=10,2 } \\
\text { A; Open Circuit Voltage } \\
\text { (Voc)=21,9 V; Max. Power } \\
\text { Current= 9,2 A, Max Power } \\
\text { Voltage: } 17,6 \text { V. }\end{array}$ & 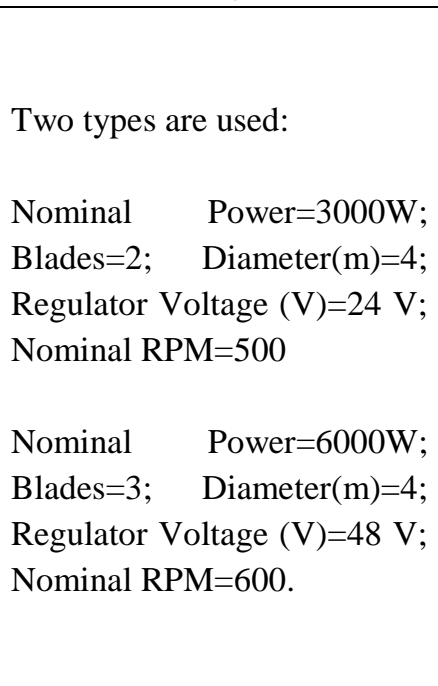 & $\begin{array}{l}\text { Three types are used: } \\
800 \text { A-h, } 1080 \text { A-h and } \\
1200 \text { A-h. All of them } 2 \\
\text { V, Vented lead-acid, } \\
\text { tubular-plate, deep- } \\
\text { cycle battery. } 20 \text { years } \\
\text { lifetime. }\end{array}$ & $\begin{array}{l}\text { Four types are used: } \\
9 \mathrm{~kW}, 14 \mathrm{~kW}, 19 \mathrm{~kW} \\
\text { and } 23 \mathrm{~kW} \text {. Fuel } \\
\text { consumption is } 0.2529 \\
\text { liters per hour per output } \\
\mathrm{kW} \text {. All of them } 60 \mathrm{~Hz} \\
\text { @ } 1800 \mathrm{RPM} \text { and } 4 \\
\text { poles PMSG, }\end{array}$ \\
\hline
\end{tabular}

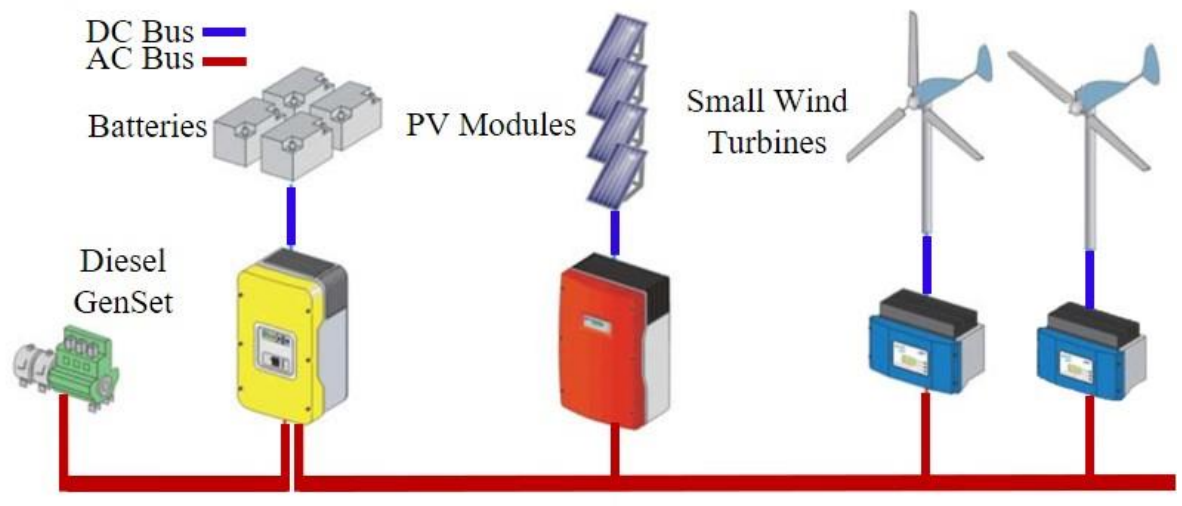

Figure 4. Layout of a renewable hybrid system.

The general control strategy (Figure 5) ranks the RET-based technologies, prioritizing PV rather than wind generation, since SWT are rotating machines requiring more frequent maintenance than PV modules. Moreover, the control strategy has three essential objectives: 1) to reliably and securely cover the electricity supply to the loads; 2) to minimize the fuel consumption and maintenance costs of the backup system, and 3) to optimize the lifetime of the batteries and the diesel generator. To do so, some predefined limit values are established in the charge regulators and battery inverters. Depending on the SOC, the battery inverter generates a start/stop signal for the diesel generator. In order to ensure optimal efficiency in fuel consumption, the diesel generator must work at full power when the RET-based generators or batteries are unable to supply the maximum peak demand (SOC>80\%). Hence, the battery inverter regulates the current of the generator to ensure it remains at its optimum operating point, even against sudden changes in the load. The aim is for the diesel generator to always operate at maximum efficiency in order to consume around $10-20 \%$ less fuel per produced $\mathrm{kWh}$ than it would under a regime at $50-75 \%$ of the nominal capacity [48]. Finally, the battery inverter also monitors the heating and load level to minimize the frequency of maintenance and significantly extend battery lifetime. 


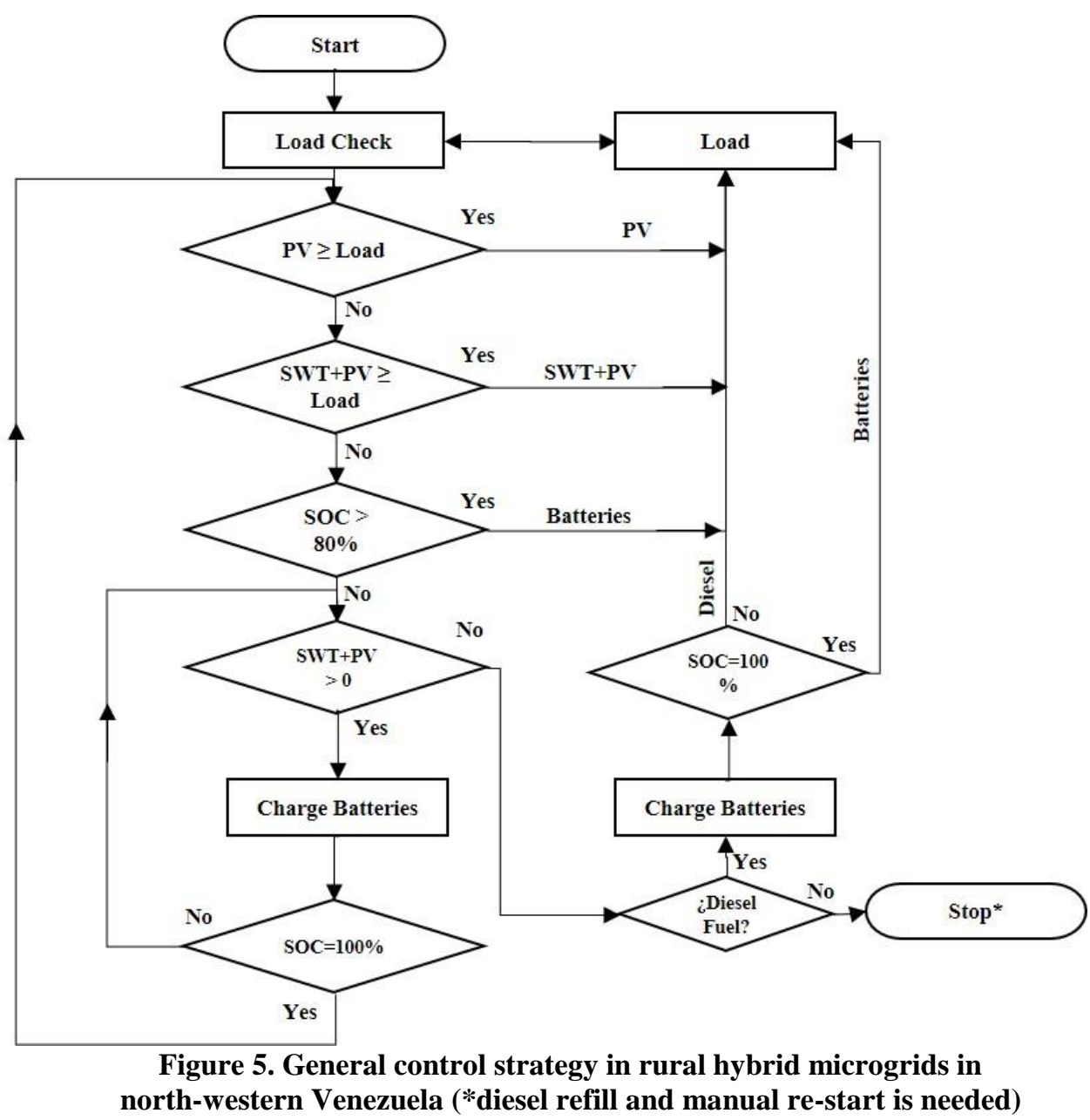

\subsection{Management model}

The management model was developed by Fundelec, taking into account the structure of the Community Councils (CC). Fundelec acts as the Autonomous Authority for Rural Electrification (AARE), working in collaboration with the Electricity Service Company (ESC), Corpoelec [22]. Both public institutions are attached to the Electricity Ministry of Venezuela, as the Regulatory Entity (RE) of the electricity sector. The RE is responsible for promoting, funding and supporting projects for sustainable development in the communities electrified by the AARE. In each community, a Community Operator ( $\mathrm{CO}$ ) is designated by the $\mathrm{CC}$. The $\mathrm{CC}$ fixes and collects the electricity rates, subsequent to the tariff approval by User Assemblies (UA). The electricity rates are used to cover minor maintenance tasks carried out by the CO. The CO is trained by the AARE to assume responsibility for the following activities: battery and diesel generator maintenance, fuel refilling, cleaning of PV panels and the microgrid surroundings, etc. In addition, the $\mathrm{CO}$ is trained to optimise the use of fuel during failures in wind-PV generators or batteries. Finally, the $\mathrm{CO}$ must notify the AARE in the event of major breakdowns. Figure 6 shows examples of the four different microgrid configurations installed in north-western Venezuela. 


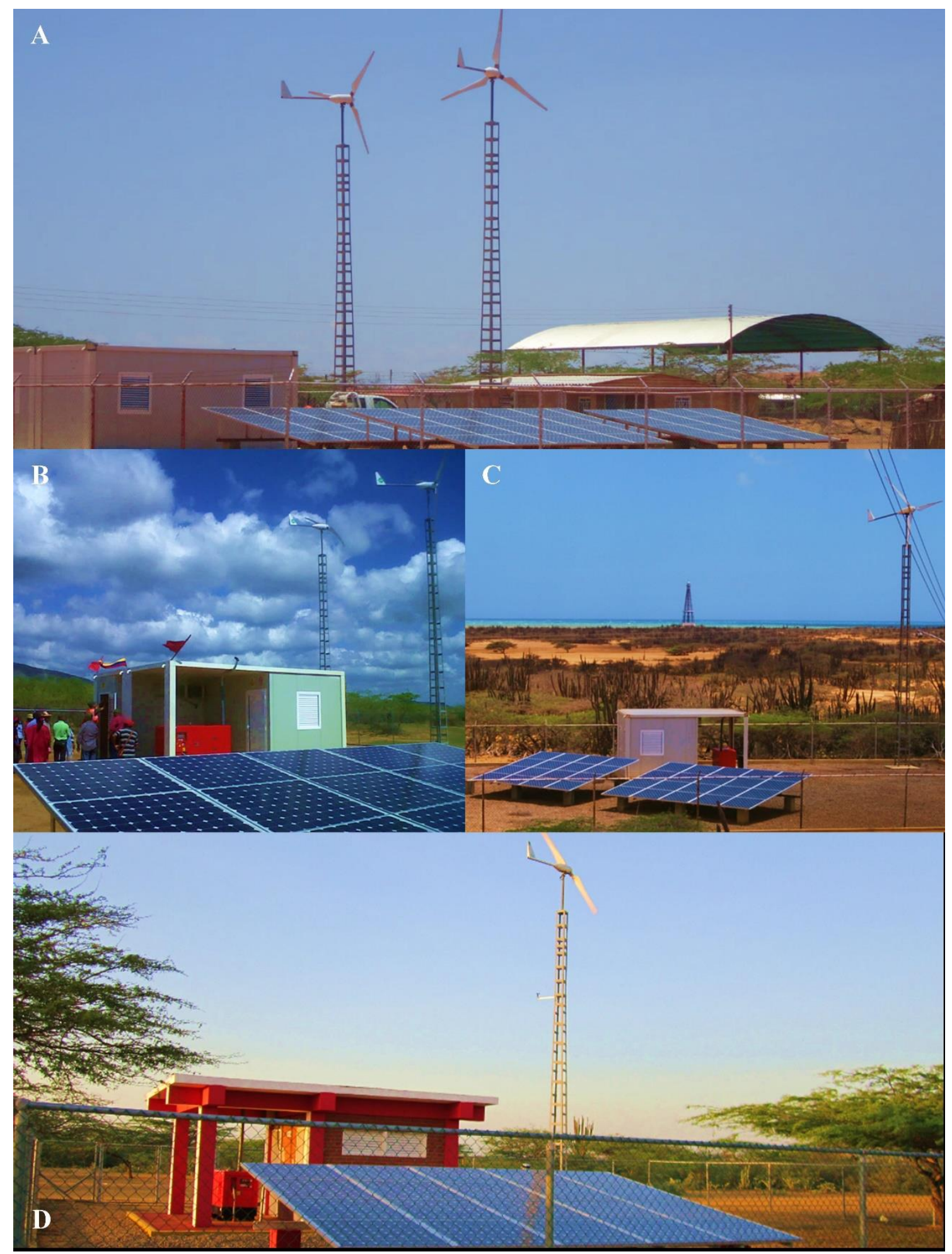

Figure 6. Examples of hybrid microgrids of different architectures: (A) SH-40 in Cusia, (B) SH-30 in Wososopo, (C) SH-20 in La Macolla and (D) SH-10 in Jacuque

\section{Evaluation methodology}

In order to obtain a comprehensive sustainability assessment, an approach based on the end-users' perspective is very important [49]. This can only be achieved through in situ visits and adequate surveys and interviews [50]. Moreover, simulations using HOMER v2.67 have been developed to evaluate the technical performance of the systems. These data gathering processes are explained in the following sections. 


\subsection{Fieldwork}

The 13 rural communities analysed in this paper, located in north-western Venezuela (Falcón and Zulia states), were visited in order to collect the in situ data. First, 9 semi-structured interviews with CO and technicians from the AARE (Fundelec) were carried out. Technical revisions were made to identify the environmental and visual impact of the projects, the possible waste and the physical condition of the equipment. Moreover, a total of 39 surveys (out of 39 benefited families) were carried out in Falcón and 67 (out of 180 families) in Zulia. In Falcón all the beneficiaries could be consulted, while in Zulia a representative sample of $37 \%$ was surveyed [51][52]. The average duration of each survey was around 15-20 minutes, and it took 16 days to carry out the 106 surveys, 5 in Falcón and 11 in Zulia, from the end of August to the beginning of September 2016.

The questionnaire was organised in 5 sections, focussing on the main aspects that have an influence on project sustainability: (1) rational use of energy and the environment; (2) demand and electricity consumption; (3) basic services; (4) educational level and productive activities, and (5) perception of the service quality. From the questionnaire, 16 sample indicators were defined to summarise the results obtained [51][52] (Table 4), organised according to their relation to the 4 proposed sustainability evaluation dimensions.

Table 4. Sample indicator results according to the surveys

\begin{tabular}{|c|c|c|c|}
\hline Indicator & Description & Value & Dimension \\
\hline$I_{1}$ & $\%$ people who claim that the microgrid produces pollution & $<1 \%$ & $\mathrm{E}$ \\
\hline$I_{2}$ & $\%$ houses where domestic diesel generators were replaced & $89 \%$ & $\mathrm{E}$ \\
\hline$I_{3}$ & Average daily consumption per house & $1.775 \mathrm{kWh} /$ day & E-T \\
\hline$I_{4}$ & End-users' perception of failure frequency & $76.1 \%$ & $\mathrm{~T}$ \\
\hline$I_{5}$ & End-users' perception of failure duration & $64.8 \%$ & $\mathrm{~T}$ \\
\hline$I_{6}$ & $\%$ houses with refrigerators or freezers & $53.7 \%$ & T-SE \\
\hline$I_{7}$ & $\begin{array}{l}\% \text { school attendance in comparison with } \\
\text { rural national average (between } 7-12 \text { years) }\end{array}$ & $74.1 \%$ over & SE \\
\hline$I_{8}$ & $\begin{array}{l}\% \text { school attendance in comparison with } \\
\text { rural national average (between 13-17 years) }\end{array}$ & $66.7 \%$ over & SE \\
\hline$I_{9}$ & $\%$ adult illiteracy in comparison with rural national average & $64.0 \%$ under & SE \\
\hline$I_{10}$ & $\begin{array}{c}\% \text { people who consider electrification has } \\
\text { a good impact on education quality }\end{array}$ & $55 \%$ & SE \\
\hline$I_{11}$ & $\begin{array}{l}\text { \% average income per capita in comparison } \\
\text { with rural national average }\end{array}$ & $0.2 \%$ over & SE \\
\hline$I_{12}$ & Average tariff amount $(\$)$ & $2 \$$ & $\mathrm{SE}$ \\
\hline$I_{13}$ & $\%$ people satisfied with the tariff & $31.5 \%$ & SE-I \\
\hline$I_{14}$ & $\%$ people satisfied with the management model & $0 \%$ & I \\
\hline$I_{15}$ & \% people satisfied with the $\mathrm{CO}$ & $65.5 \%$ & SE-I \\
\hline$I_{16}$ & $\%$ people satisfied with institutional commitment & $32.1 \%$ & I \\
\hline
\end{tabular}

\subsection{Simulations}

In the evaluation phase, HOMER v2.67 software is used to evaluate the performance of the electrification systems, focussing on real energy generation and real load profiles. First, the generation performance is determined from the energy resources (wind and solar) obtained from satellite databases, with an accuracy of $200 \mathrm{~m}$ [31]. The wind profiles are adjusted at the hub height, considering wind shearing data obtained from measurements taken at different heights by ENELVEN, the Electrical Energy company of Venezuela, over a period of more than 5 years. Next, the load profile is calculated from the surveys: the number of electrical appliances and usage hours. Figure 7 shows the average daily profile for rural communities in Falcón and Zulia. In all the communities, the peak load is reached in the 18 to $22 \mathrm{~h}$ period, as most of the electricity consumption comes from lighting, radio, TV and other appliances used at night. Therefore, the 
load factor is high in most of the communities because the daily load average tends to be low and constant except for night hours (peak demand). There are no noticeable seasonal changes in the daily load profile, as hours of daylight are almost constant throughout the year, as well as the climate and temperature (latitude $10^{\circ} \mathrm{N}$ ). The profiles of Zulia and Falcón are also very similar because of the determinant factors in climate conditions.
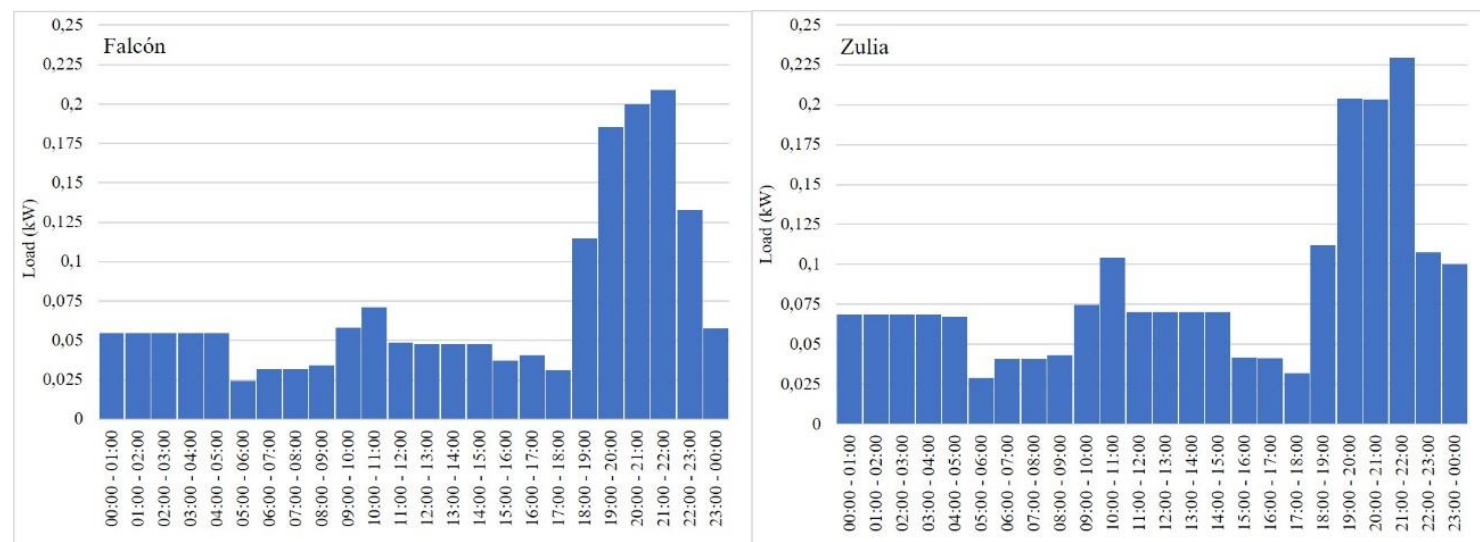

Figure 7. Daily load profiles for Zulia and Falcón communities.

In HOMER v2.67, the DC buses of the SWT, PV modules and batteries are taken together; while a single bidirectional inverter is considered, including the rectifier from the diesel genset to the batteries. As a result, a mixed architecture is virtually assembled in HOMER to analyse the behaviour of the real installed system, which has no incidence results for this investigation. Figure 8 shows the virtual mixed AC/DC architecture corresponding to the 4 microgrid configurations: Jacuque (SH-10), with a $3 \mathrm{~kW}$ wind turbine; La Macolla (SH-20), with a single $6 \mathrm{~kW}$ wind turbine; Wososopo (SH-30), where $3 \mathrm{~kW}$ and $6 \mathrm{~kW}$ wind turbines are shown, and Cusia (SH-40), where two $6 \mathrm{~kW}$ wind turbines can be observed.

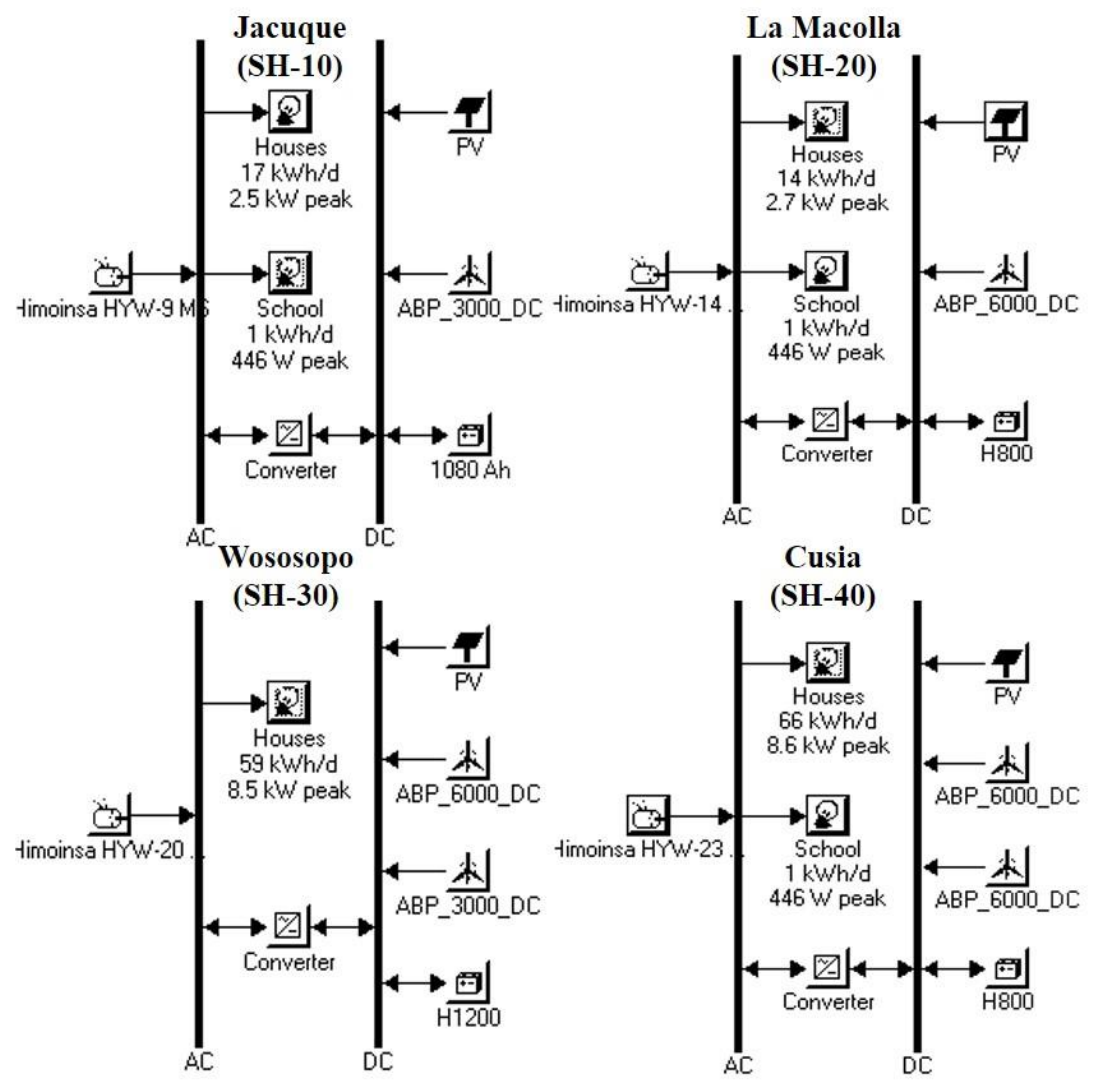

Figure 8. Mixed AC/DC architecture in HOMER v2.67 simulation schemes of hybrid microgrids for communities in north-western Venezuela 
The simulation results show that the SOC remains at over $80 \%$ during a typical year in 12 out of the 13 communities (Figure 9). Jacuque is the only exception, being $76 \%$ of the time over $80 \%$ of the SOC, because the load/generation ratio is higher than in the other communities. Figure 9 also shows the daily load profile for Macuirrapa, where the relationship between the wind-PV generation and the SOC can be easily understood.

\begin{tabular}{|c|c|}
\hline Communities & $\begin{array}{c}\text { Percentage of Time } \\
\text { SOC is over } 80 \%\end{array}$ \\
\hline Prudencio & $99.9 \%$ \\
\hline Jacuque & $76.0 \%$ \\
\hline La Macolla & $100.0 \%$ \\
\hline Los Arroyos & $100.0 \%$ \\
\hline Poloos & $99.9 \%$ \\
\hline Taparo & $99.4 \%$ \\
\hline Iramacira & $100.0 \%$ \\
\hline Wososopo & $91.4 \%$ \\
\hline Machuaiya & $99.9 \%$ \\
\hline Castilletes & $100.0 \%$ \\
\hline Cúsia & $99.8 \%$ \\
\hline Macuirrapa & $95.8 \%$ \\
\hline Punta Manglar & $99.7 \%$ \\
\hline
\end{tabular}

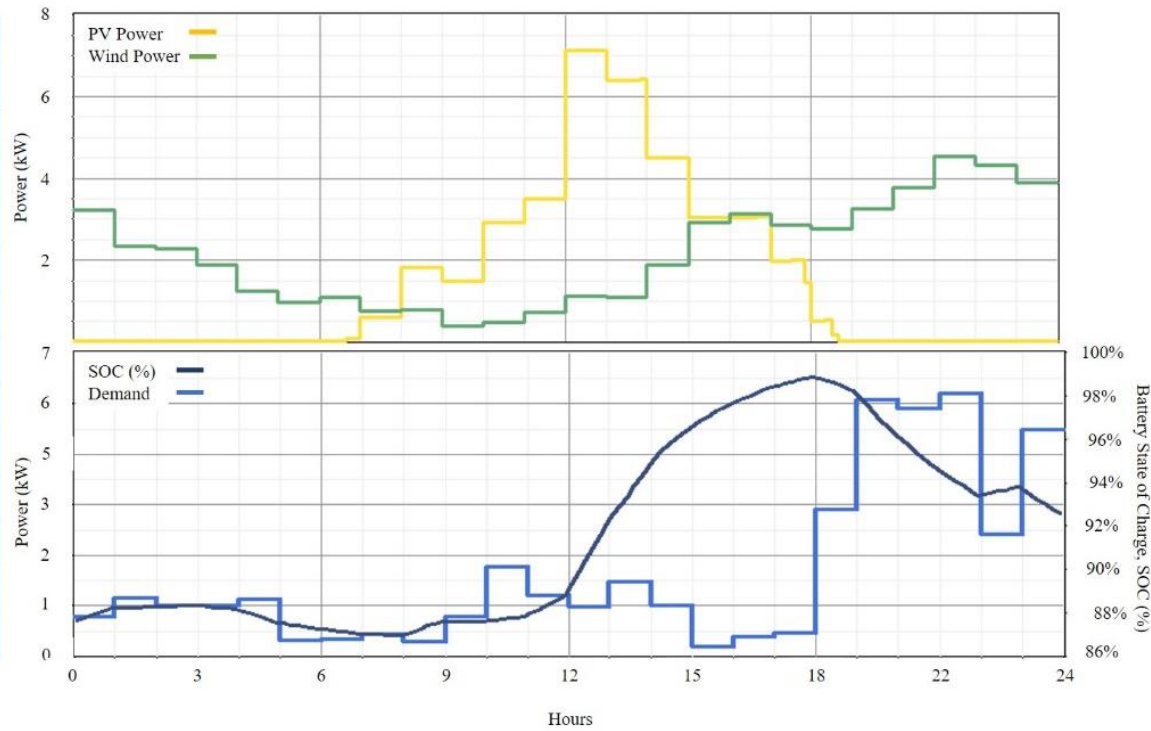

Figure 9. Typical day in Macuirrapa: (above) PV and wind generation; (below) daily load demand and SOC. The table shows the annual percentage of time with SOC over $80 \%$ for the studied communities

Results from HOMER v2.67 simulations are used to calculate the indicators for the Venezuelan project evaluation presented in the next section. In particular:

- Regarding the environmental dimension, the emission factor in rural hybrid microgrids comes from the diesel backup system. The simulation considers the load profile, the available renewable energy sources and the battery capacity. Consequently, the emission factor is obtained as the emission rate for the operation of the diesel system and the total energy generated $\left(\mathrm{CO}_{2} / \mathrm{kWh}\right)$. Simulations are carried out according to the normal operation and failure conditions of a RET (N-1) [53]. The results are compared with the emissions from alternative electrification schemes (Figure 10): (a) electrical system in north-western Venezuela; (b) individual diesel generation, and (c) community diesel generation.

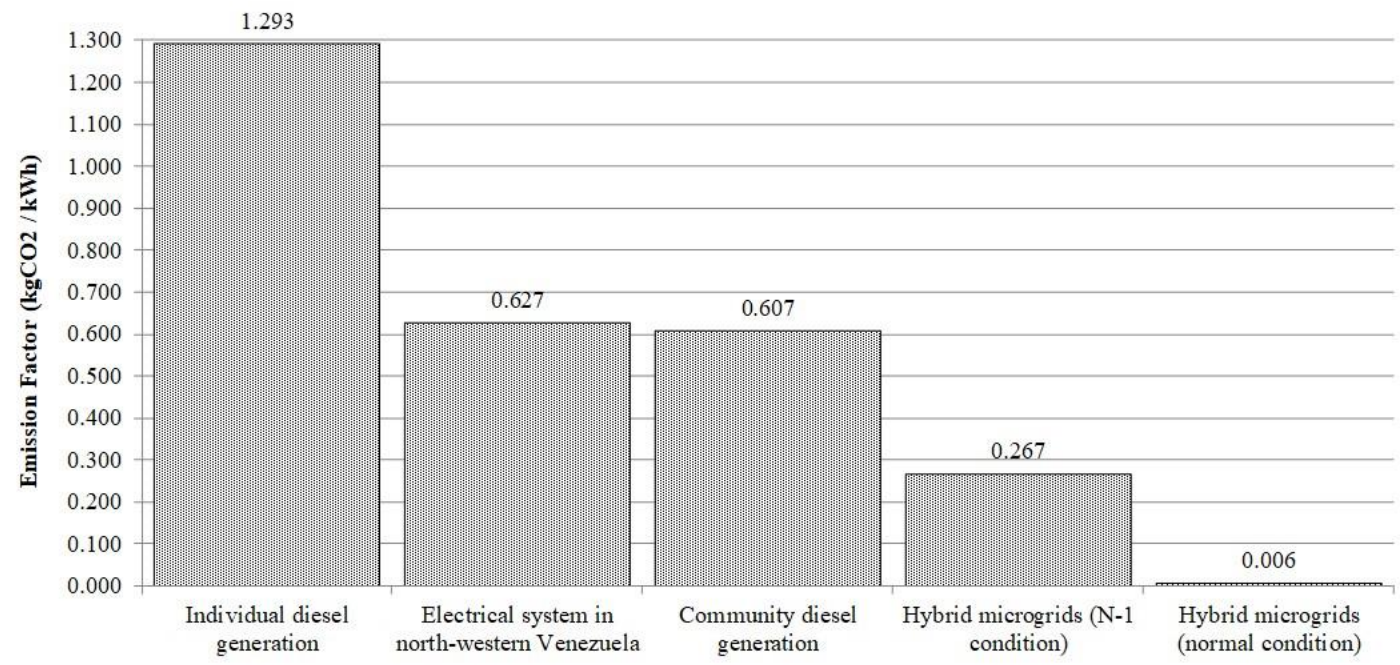

Figure 10. Emission factors of studied communities according to the rural electrification technology 
- Regarding the technical dimension, the adequacy and reliability of the system are obtained by studying the daily load profile gathered from surveys and the electricity generation results from HOMER v2.67. The electricity generation is a function of the available energy resources (satellite data) and technology performance (specification sheet), obtained during the field-work. Thus, the average daily consumption per community and house is compared to the generating capacity of the hybrid microgrid, according to the available resources [21], as shown in Figure 11.

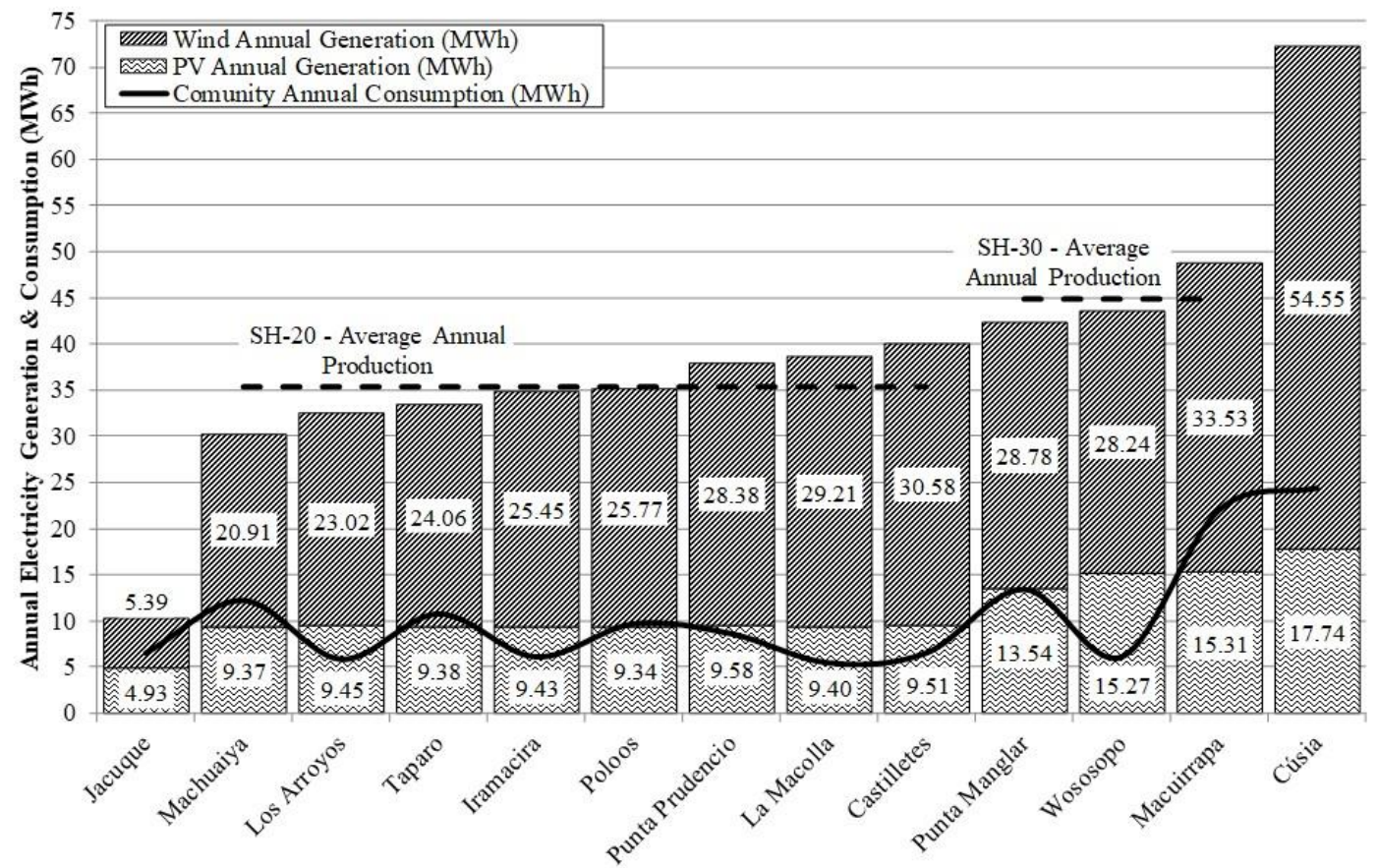

Figure 11. Average annual electricity generation and community consumption in hybrid microgrids of north-western Venezuela, based on HOMER v2.67 simulations and end-user surveys

\section{Project comparison and results analysis}

In this section, the 4 sustainability dimensions are assessed: environmental (Section 4.1), technical (Section 4.2), socioeconomic (Section 4.3) and institutional (Section 4.4). For this purpose, some ad hoc specific criteria are proposed for each dimension. Table 5 shows the data used to evaluate each criterion: the indicators generated from the surveys, the information obtained in the technical visits, the results of the HOMER simulation or National statistics databases.

Table 5. Evaluation elements for each of the criteria considered for sustainability dimensions

\begin{tabular}{|c|l|c|}
\hline Dimension & \multicolumn{1}{|c|}{ Criteria } & Evaluation Data \\
\hline \multirow{4}{*}{ Environmental } & Impact on local ecosystems (E-1) & $I_{1}, I_{3}$, Technical Visits \\
\cline { 2 - 3 } & Technology dissemination and technological change (E-2) & $I_{2}, I_{3}$ \\
\cline { 2 - 3 } Technical & Emission mitigation (E-3) & HOMER v2.67 simulation \\
\cline { 2 - 3 } & Adequacy (T-1) & $I_{3}, I_{6}$ \\
\hline \multirow{5}{*}{ Socioeconomic } & Reliability (T-2) & $I_{4}, I_{5}, I_{6}$, HOMER v2.67 simulation \\
\cline { 2 - 3 } & Education (SE-1) & $I_{7}, I_{8}, I_{9}, I_{10}$, National Data \\
\cline { 2 - 3 } & Health (SE-2) & $I_{6}$, National Data \\
\cline { 2 - 3 } & Community participation (SE-3) & $I_{13}, I_{15}$ \\
\cline { 2 - 3 } & Effordability and sustainability of electricity rates (SE-4) & $I_{12}$ \\
\cline { 2 - 3 } & Energy poverty reduction (SE-5) & $I_{11}, I_{12}$, National Data \\
\hline \multirow{5}{*}{ Institutional } & $I_{13}, I_{14}, I_{15}, I_{16}$ \\
\cline { 2 - 3 } & Institutional alignment and relationship with communities (I-1) & $I_{13}$ Technical Visits, National Data \\
\cline { 2 - 3 } & Economic sustainability of the program (I-2) & Technical Visits \\
\cline { 2 - 3 } & Sustainable development goals (I-3) & \\
\hline
\end{tabular}




\subsection{Environmental dimension}

The environmental dimension is evaluated considering the possible impact of hybrid microgrids on the environment, the natural resources and the ecosystems of the community locations [18]. This impact can be reflected at a local, regional and global level [54]. For example, the use of fuel or kerosene lamps has an effect on the air pollution within houses (local impact), deforestation (regional impact) and the atmospheric concentration of greenhouse gas emissions (global impact). From the investigations of Brent et al. [55], Ilskog [18] and Munasinghe [17], 3 criteria have been defined for evaluating the environmental sustainability dimension:

- Impact on local ecosystems (E-1): In none of the 13 visited communities have polluting residues been produced. Similarly, no negative impact has been found on the flora or fauna of community ecosystems, not even birds killed by impact with turbine blades [6]. A negative impact is reported in only one house of Falcón, located at less than $15 \mathrm{~m}$ from the wind turbine, regarding the noise from blades during wind gusts. The evaluation for this criterion is positive.

- Technology dissemination and technological change (E-2): Before the electrification, most of the houses had individual diesel generators. After implementing the hybrid microgrids, $89 \%$ of the houses have abandoned these generators and only $11 \%$ keep them as a backup. Globally, 190 individual diesel generators have been replaced as a result of the hybrid microgrid connection. The evaluation for this criterion is positive.

- Emission mitigation (E-3): Even under the N-1 condition, hybrid microgrids have an emission factor $80 \%$ lower than individual diesel generators, $56 \%$ lower than the national grid extension and 55\% lower than community diesel generation. The evaluation for this criterion is positive.

As a result of the environmental dimension, the three criteria analysed for the sustainability evaluation of hybrid microgrids are positive. Therefore, these rural electrification systems are environmentally sustainable.

\subsection{Technical dimension}

The technical dimension is related to specific aspects of microgrid operation and could be defined in terms of the safety and quality of the energy supply. This in turn depends on the supply being available on a regular and reliable basis and of standard quality, according to the given regulatory framework [56]. These aspects of the technical dimension are integrated into other sustainability dimensions, such as the environmental or socioeconomic [18]. In this sense, the technical dimension is closely linked to the achievement of universal access to reliable and modern energy, according to the seventh goal of the 2030 Agenda [57]. Therefore, 2 criteria are considered for the evaluation of the technical sustainability: adequacy and reliability. The adequacy of a technology is based on a comparison with the minimum electricity threshold required to meet specific energy needs [58]. Regarding reliability, an energy supply must be available on a regular and reliable basis in order to be considered adequate [56].

- Adequacy (T-1): The weighted average consumption per house in Falcón and Zulia communities is $1.775 \mathrm{kWh} /$ day, representing $88.75 \%$ of the value considered during the design (Section 2.1). Nevertheless, it can be observed how demand can be globally supplied by solar PV technology, while wind turbines are used to cover daily demand fluctuations. In addition, these community demand values represent between $34 \%$ and $95 \%$ of the typical electricity consumption of rural houses connected to the north-western electrical system of Venezuela [28]. In other words, the technical design of hybrid 
microgrids is consistent with the real consumption of beneficiaries and the rural population in similar socioeconomic conditions. The evaluation for this criterion is positive.

- Reliability (T-2): $76.1 \%$ of end-users consider that hybrid microgrids have a low failure rate and $64.8 \%$ perceive a short duration for failures. Failures and their duration are directly related to the quality of maintenance and speed of repairs. However, the fundamental factor is the size and design values considered for these projects. Indeed, thanks to the system's highly reliable performance (Figure 11), the consistency of the generating, storage and backup capacity of hybrid microgrids with average consumption in electrified communities is favourable. The average annual consumption of communities does not in any case exceed $63 \%$ of the generating capacity. The evaluation for this criterion is positive.

As a result, in the technical dimension the 2 criteria implemented for the evaluation of hybrid microgrids are positive, so this technology can be considered technically sustainable.

\subsection{Socioeconomic dimension}

This is the most complex dimension of sustainability [59], since all the criteria considered for the evaluation are linked to another dimension. As the social and economic criteria are closely related, a single dimension is proposed. In both aspects, the evaluation criteria must be related to the characteristics of sustainable development, established in the Brundtland report [16] and analysed in detail by Munasinghe [17] for the specific field of energy.

In social terms, the evaluation criteria include the concepts of community empowerment, inclusion and governance [16]. The key aspects to ensure the social sustainability of hybrid microgrids are: end-users' participation (empowerment), the promotion of equity in access to energy and basic services such as education and health (inclusion), and the reduction of social vulnerability in terms of school dropout rates, illiteracy and diseases. Governance is related to strengthening the institutions involved and the social values that are enhanced through education [17]. Consequently, 3 criteria are considered for the evaluation of social sustainability: education, health and community participation.

In economic terms, 3 criteria are considered: the affordability and sustainability of electricity rates, the improvement in productivity and the reduction of energy poverty. Thus, three key aspects are considered respectively: energy equity, productive growth and energy poverty. Equity is related to the ability to pay for and have access to a quality electricity service [54], with a reliable supply that allows productive activities to be carried out [16]. Productive growth is related to the ability to increase incomes through the use of electricity. Regarding energy poverty, no consensus has been reached on its nature and definition [60]. However, the most common quantitative indicators are: (1) Low Income, High Cost (LIHC) [61], (2) Minimal-Standard (MIS) [62], and (3) The TenPercent-Rule (TPR) [63] [64]. On the one hand, the LIHC and MIS indicators are very precise in local contexts, but are generally complex to estimate at a regional or international level. On the other hand, the TPR is easier to estimate and considers as energy poor those people who have to spend more than $10 \%$ of their net income on adequate energy services [60]. Indeed, thanks to TPR's simplicity, easy communicability and versatility, it has become the most used indicator for energy poverty and is the indicator considered in this assessment.

- Education (SE-1): In the Wayuú indigenous communities of Zulia, the rate of basic and secondary education has increased after the installation of microgrids. Among children aged from 7 to 12 (basic education), school attendance is $74.1 \%$ higher than the national average for rural indigenous communities [65]. For ages ranging from 13 to 17 years, attendance in secondary education is $66.7 \%$ higher than the national average for this social 
group [65]. In addition, the illiteracy rate is $64 \%$ lower than the indigenous national average [65]. On the other hand, the non-indigenous communities of Falcón show no significant improvements in the education rates since those communities were already at an average level before electricity access. In other words, the impact on education is greater in communities which, previously, had low educational levels. Finally, 55\% of respondents in Falcón and Zulia believe that electrification has had a positive impact on education quality for children and teenagers.

Education is also related to access to information and telecommunications. In this sense, $69.0 \%$ of the indigenous houses electrified in Zulia and $78.6 \%$ in Falcón have acquired a TV since electrification. Moreover, in $42 \%$ of the houses in Falcón, one family member has regular access to internet; this figure is almost 10 times higher than in nearby villages (4.65\%) [25]. The evaluation for this criterion is positive.

- Health (SE-2): After electrification, $47.6 \%$ of the houses in Zulia and $64.3 \%$ in Falcón were able to install refrigerators or freezers, a very important step considering that the average annual temperature exceeds $30^{\circ} \mathrm{C}$ [34]. In the indigenous communities of Zulia, this is $62 \%$ higher than the average for the non-electrified Wayuú population [25]. Taking into account that many communities have a diet based on shellfish and goat meat, refrigeration prevents most pathogens, so food will keep safe for a longer time [66]. It also enables the preservation of food for children under 5 years, thereby reducing infant mortality [67]. Additionally, electric lighting replaces kerosene lamps. The latter produce lung-damaging gases and particles which increase the rates of illnesses such as tuberculosis, asthma or cancer [68]. The evaluation for this criterion is positive.

- Community participation (SE-3): $65.5 \%$ of beneficiaries consider that Community Operators (CO) are well-trained and have been efficient in maintaining hybrid microgrids. In general, the Community Councils (CC) manage the microgrids efficiently. The collection of electricity rates is effective, given the acceptance of $\mathrm{CO}$ among end-users. In addition, beneficiaries have appropriated the electrification systems and they ensure the adequate maintenance of equipment after 5 years of continuous operation. In this regard, the participatory management model has made it possible to keep RET-based facilities operative during that time. However, most users suggest the need for a change in the management model in order to make hybrid microgrids more self-sufficient from the national electricity sector. The evaluation for this criterion shows elements of the social dimension in need of improvement.

- Affordability and sustainability of electricity rates (SE-4): End-users pay between $\$ 1$ and $\$ 3$ per house per month to cover minor O\&M costs. This tariff is established through User Assemblies (UA) and may vary according to the expenses of maintenance activities each month. However, the collected amount does not even cover $10 \%$ of the annual O\&M costs (including expenses assumed by the government and free for beneficiaries), nor are capital costs recovered. Table 6 shows the income percentage of the families spent on energy supply when using: the current hybrid microgrids (column 2), individual diesel generators (column 3), hybrid microgrids assuming all the O\&M costs (column 4) or hybrid microgrids assuming the levelized cost of electricity, LCOE (column 5). Therefore, the current electricity rates are, on the one hand, affordable. On the other hand, they do not allow communities to be self-sufficient. Consequently, economic sustainability in the medium and long term is not guaranteed under this scheme. Indeed, $68.5 \%$ of end-users consider that the tariff should be fixed and cover all O\&M annual expenses. The evaluation for this criterion shows elements of the social dimension in need of improvement. 
Table 6. Percentage of family incomes of different aspects for communities electrified with hybrid microgrids in north-western Venezuela

\begin{tabular}{|c|c|c|c|c|}
\hline \multirow{2}{*}{ State } & \multicolumn{4}{|c|}{ Tariff as percentage of family incomes } \\
\cline { 2 - 5 } & Current tariff & Individual diesel & O\&M & LCOE \\
\hline Falcón & $0.62 \%$ & $12.00 \%$ & $16.64 \%$ & $26.10 \%$ \\
\hline Zulia & $2.53 \%$ & $17.00 \%$ & $32.24 \%$ & $45.82 \%$ \\
\hline
\end{tabular}

- Energy poverty reduction (SE-5): The financial cost for families is studied, considering the average monthly incomes. First, as $89 \%$ of beneficiaries have stopped using individual diesel generation, hybrid microgrids have reduced the cost of electricity by $90 \%$ (mainly fuel saving costs), allowing families to overcome energy poverty. Indeed, Table 6 shows that the financial cost is now below the energy poverty threshold, which is generally considered to be around $10 \%$ of the monthly family budget [69]. Therefore, this criterion shows an effective reduction in energy poverty, which is positive with regard to individual diesel.

- Improvement in productivity (SE-6): The productive activities and the average income per house and person in each community are determined (Table 6). According to a study carried out by the Central Bank of Venezuela [70], the average rural income per capita in 2005 for non-electrified communities was \$2.10/day. According to end-user surveys, the weighted average per capita income in non-indigenous communities is $\$ 4.02 /$ day, while for the indigenous population this value is $\$ 0.99 /$ day. Thus, $28.8 \%$ of hybrid microgrid beneficiaries have increased their incomes after electrification, with the average income growth being $60.1 \%$. The largest increase is observed in the fishing communities of Prudencio and La Macolla (Falcón), where seven government microcredits have been granted for the acquisition of boats and outboard engines. Among the three main activities in the target communities (fishing, goat farming and handicrafts), the average income for fishing activities outstrips the others (Table 6). This is due to the impact of electrification, which has led to an increase in fishing thanks to the refrigerated storage capacity. On the other hand, regarding goat farming, improvements have only had an impact on the conservation of dairy products. This is a marginal activity at a community level, producing very little income in comparison with the direct sale of goats, which doesn't need electricity. Finally, concerning the manufacture of handicrafts, although the number of light hours for crafting has increased, the impact is not significant in terms of productivity. In Table 7, the indigenous and non-indigenous communities are differentiated. Note that the poverty line is considered at $\$ 1.90$ per person per day [71]. Most of the indigenous population electrified with hybrid microgrids remain below this threshold; while nonindigenous families mostly exceed that value (Jacuque and Castillete only represent 14 houses). The improvement in productivity is uneven, as some aspects of population were not considered during the program design. The evaluation for this criterion shows elements of the social dimension in need of improvement.

As a result of the socioeconomic dimension, there is a clear difference between the social and economic outcomes. In the Wayuú indigenous communities (Zulia), the socioeconomic improvement is focussed on social aspects, where very positive advances have been observed in education and health. On the other hand, in the non-indigenous communities (Falcón), which already had better education and health levels, the improvement is more significant in economic and productive aspects. It can then be inferred that there will be an economic improvement for the Wayuú population in the medium and long term, after their social conditions are consolidated. In short, hybrid microgrids promote the sustainable development of the socioeconomic dimension, although at different rates depending on the beneficiaries' previous conditions. Therefore, hybrid microgrids are sustainable in their socioeconomic dimension. 
Table 7. Incomes and productive activities in communities electrified with hybrid microgrids

\begin{tabular}{|c|c|c|c|c|c|}
\hline Region & Community $^{1}$ & $\begin{array}{c}\text { Productive } \\
\text { activity }\end{array}$ & $\begin{array}{c}\text { Community } \\
\text { productive } \\
\text { incomes } \\
{[\$ / \text { month }]} \\
\end{array}$ & $\begin{array}{c}\text { Per capita } \\
\text { productive } \\
\text { incomes } \\
\text { [\$/day] }\end{array}$ & $\begin{array}{c}\text { Family } \\
\text { productive } \\
\text { incomes } \\
{[\$ / \text { day }]}\end{array}$ \\
\hline \multirow{4}{*}{ Falcón } & Prudencio & Fishing & 6,668 & 6.35 & 18.52 \\
\hline & Jacuque & Goat breeding & 1,127 & 1.14 & 4.70 \\
\hline & La Macolla & $\begin{array}{c}\text { Fishing } \\
\text { Goat breeding }\end{array}$ & 5,755 & 5.99 & 27.40 \\
\hline & Los Arroyos & Fishing & 4,477 & 3.64 & 12.44 \\
\hline \multirow{9}{*}{ Zulia } & Poloos* & $\begin{array}{c}\text { Fishing } \\
\text { Goat breeding }\end{array}$ & 9,845 & 2.17 & 13.67 \\
\hline & Taparo* & Goat breeding & 1,695 & 0.64 & 3.77 \\
\hline & Iramacira* & Handicrafts & 1,659 & 0.76 & 3.95 \\
\hline & Wososopo* & Goat breeding & 3,161 & 0.69 & 4.05 \\
\hline & Machuaiya* & Goat breeding & 3,132 & 1.05 & 6.14 \\
\hline & Castilletes & Fishing & 1,782 & 1.52 & 9.90 \\
\hline & Cusia* & Handicrafts & 5,214 & 1.03 & 4.83 \\
\hline & Macuirrapa* & $\begin{array}{c}\text { Fishing } \\
\text { Goat breeding }\end{array}$ & 2,860 & 0.45 & 3.67 \\
\hline & Punta Manglar & $\begin{array}{c}\text { Fishing } \\
\text { Goat breeding }\end{array}$ & 8,582 & 3.14 & 17.88 \\
\hline
\end{tabular}

\subsection{Institutional dimension}

The institutional dimension is directly linked to the environmental, technical and socioeconomic performance [18]. The following criteria are considered when assessing institutional sustainability: 1) institutional alignment and relationship with communities [70], defined as the capacity of institutions to organise their functions, facilitate projects' sustainable performance and establish a positive relationship with communities; 2) economic sustainability of the program [71], which is the institutional capacity to sustain fulfilment of the medium and long-term commitments in terms of the project's economic sustainability, and 3) sustainable development goals [57], and how the program contributes to their achievement.

- Institutional alignment and relationship with communities (I-1):74.4\% of indigenous communities (Zulia) and 55.2\% of non-indigenous ones (Falcón) consider that the institutions have not been diligent in carrying out their assigned O\&M tasks, according to the management model. Therefore, they are willing to pay more for the electricity service in exchange for expanding their management capacity for O\&M tasks and increasing their self-sufficiency. However, when the institutional alignment is effective, productive improvements can be observed. For example, 7 micro-credits were granted in La Macolla and Prudencio (Falcón), leading to an increase in productivity and incomes. Another positive aspect regarding the institutional alignment is observed in indigenous communities. Here, a clear increase in the school attendance rate is the result of a greater availability of teachers, thanks to salary incentives and better conditions due to electricity. However, the per capita incomes have not risen for the indigenous population, not even above the poverty line [71]. Therefore, this criterion shows that the institutional alignment has been effective in promoting social development, while for economic development only a partial improvement has been confirmed, especially for population with some previous education level.

- Economic sustainability of the program (I-2): considering the total number of houses electrified with hybrid microgrids and the projection of savings in opportunity costs for fuel over a period of 20 years, the Internal Rate of Return (IRR\%) of the microgrid configurations is: $6.2 \%, 8.2 \%, 11.2 \%$ and $13.0 \%$ for systems up to $10,20,30$ and 40 houses, respectively. In each case the $15 \%$ threshold set by the Venezuelan state oil 
company for such programs is not exceeded [72]. In order for the program to be economically sustainable at an institutional level, an additional tariff must be established under the conditions described in the evaluation of criterion SE-4 (Section 3.3). Therefore, this criterion shows that measures must be taken to guarantee, through economic support, the medium and long term sustainability of such programs in Venezuela.

- Sustainable development goals (I-3): rural electrification with hybrid microgrids has an impact on 15 out of 17 Sustainable Development Goals [57]. All the dimensions of sustainability evaluated in the previous sections have one or more objectives within the goals of sustainable development, which goes to prove the broad impact of electrification in reaching national and global institutional targets. Therefore, this criterion shows a positive direction of the program in terms of meeting these goals, at least in the short and medium term. The evaluation for this criterion is positive.

As a result of the evaluation of the institutional dimension, some improvements must be made in order to consolidate the economic development of the program in the medium and long-term, regarding maintenance by the institutions responsible for such tasks. Thus, the beneficiaries' perception of the economic sustainability of the program will improve if the AARE carries out the required maintenance activities promptly. On the other hand, institutional links should be strengthened to promote productivity development, not only in communities with previous social development, but also in those where previous social exclusion levels are higher, such as the indigenous population of Zulia. Therefore, hybrid microgrids are not properly supported by the corresponding institutional organization, and improvements must be implemented to ensure their medium and long-term sustainability.

\section{Discussion about sustainability assessment results}

This section analyses and discusses the results obtained from the criteria used for the evaluation of hybrid microgrids in north-western Venezuela, according to the 4 sustainability dimensions.

First, the combination of the wind and solar technologies is positive and allows a continuous and reliable electricity service to be provided on an hourly, daily, seasonal and yearly basis. In this regard, it can be observed (Figure 11) that the design and sizing (T-1) of hybrid microgrids in Venezuela has had a basic PV generation support. Through HOMER v2.67 simulations, it can be seen that the wind generation aims to cover daily fluctuations in the demand profiles of communities. In other words, although in global terms the PV generation meets the energy demand, in relative terms the wind is necessary to avoid supply cut offs caused by hourly or daily peaks in demand (T-2). Therefore, the usefulness of SWT is proved in regions with sufficient wind resources. The results also show that, as long as the houses are suitably distributed, hybrid microgrids are more adequate and reliable than individual systems (solar home systems or homebased wind turbines). It has also been determined, from HOMER v2.67 simulations, that the emission factors are still lower than those from national grid extension and community or individual diesel generators $(E-3)$, even in conditions of equipment failure ( $\mathrm{N}-1$ condition). Hence, the combination of technologies for the design and sizing of hybrid microgrids is fundamental in reaching high levels of adequacy $(T-1)$ and reliability $(T-2)$. This promotes a technological change $(E-2)$ towards electrification systems that pollute less than diesel generators, thus reducing the environmental impact $(E-1)$. As a result, the environmental dimension is improved.

Secondly, the adequacy $(T-1)$ and reliability $(T-2)$ of hybrid microgrids have an impact on enduser energy uses, which in turn determine the improvements in the environmental and socioeconomic sustainability dimensions. In this sense, access levels to energy have allowed most of the indigenous and non-indigenous benefited houses to have televisions (SE-1) and refrigerators 
(SE-2), at higher percentages than the average for similar non-electrified communities of the region $(S E-5)$. Considering the poverty levels in those communities, the low electricity costs ( $S E$ 4 ) have been an important factor in bringing about technological change $(E-2)$. Consequently, a significant enhancement of the environmental dimension is produced by replacing the individual diesel generators previously used in the communities. Thus, a clear relationship between the design adequacy of hybrid microgrids (technical dimension) and the emissions mitigation (environmental dimension) is established. Additionally, access to telecommunications (SE-1) and refrigerators $(S E-2)$, has a positive repercussion on education and health conditions (socioeconomic dimension). This shows the relationship between the environmental, technical and socioeconomic sustainability dimensions.

Thirdly, electricity access has a higher impact on social aspects of the socioeconomic dimension in communities with lower development levels (Wayuú indigenous villages from Zulia), while it has a greater impact on economic aspects in communities with higher development levels (Falcón). This is particularly relevant when looking at the education $(S E-1)$ and health $(S E-2)$ criteria of the Wayuú population, as well as the productivity improvement $(S E-6)$ criteria of the non-indigenous communities. This proves how the impact of rural electrification on the socioeconomic dimension of communities is directly linked to their social development prior to electricity access.

Finally, the population is committed to the maintenance of hybrid microgrids through community participation (SE-3). Therefore, an adequate institutional alignment (I-1) is fundamental for the rural electrification stakeholders: the regulatory entity, the communities, and other institutions involved in rural development. This alignment must be progressively improved in order to ensure the economic sustainability of these programs $(I-2)$. Only in this way can it be guaranteed that communities receive both electrification and the institutional support for their specific socioeconomic needs, so as to progress towards the Sustainable Development Goals of the 2030 Agenda of the United Nations (I-3).

\section{Conclusion}

In this work, a sustainability evaluation is carried out on hybrid wind-PV-diesel-battery microgrids implemented in north-western Venezuela. The projects are part of a government strategy to promote electricity access in isolated poor regions using renewable energy, under the program "Sowing Light". The evaluation is carried out following a proposed methodology, which considers 4 sustainability dimensions: environmental, technical, socioeconomic and institutional. Each dimension is assessed using ad hoc criteria to evaluate specific aspects of each project. The information for the evaluation is gathered from visits to 13 benefited communities located in Falcón and Zulia. During the visits, 106 end-user surveys are carried out as well as 9 semistructured interviews, collecting information about the socioeconomic conditions of the population, the electricity demand, the management model and the electricity rates. Moreover, HOMER v2.67 simulations of the hybrid microgrids are made in order to provide an in-depth analysis of the technical performance of the systems.

As a result of the sustainability evaluation, in the first place the wind-PV combination can provide a reliable electricity service to end-users, utilising the PV technology for basic supply and the wind to cover peaks in demand. In addition, when the houses are not excessively scattered, hybrid microgrids are more suitable than individual systems. Even assuming equipment failures $(\mathrm{N}-1$ conditions), the emission factors are lower than other supply options. Moreover, the adequacy and reliability of microgrids strengthen the technological shift towards less polluting technologies, reducing the environmental impact. Secondly, microgrids have a wide acceptance among endusers, since the design directly responds to the population's energy needs. When comparing 
indigenous and non-indigenous beneficiaries, the impact of electricity access on productivity is determined by the previous social development of communities, and especially their education and health conditions. Finally, although the population is committed to projects' maintenance, the institutional alignment of stakeholders must be progressively improved to ensure the medium and long term economic sustainability of the program.

The results of this research can be useful for rural electrification promoters in other developing countries. In this regard, the evaluation shows that hybrid microgrids in Venezuela have been an efficient tool in achieving the seventh objective of the Sustainable Development Goals of the 2030 Agenda of the United Nations.

\section{Acknowledgments}

This research was funded by the Spanish Ministry of Science and Innovation (project ENE 2015-67253-R) and the Centre for Cooperation Development (CCD) of Universitat Politècnica de Catalunya - Barcelona Tech (UPC). The work has been possible in collaboration with engineers and technicians from Fundelec, Corpoelec, social organisations and people from community councils and benefited communities in Falcón and Zulia (Venezuela).

\section{References}

[1] REN21. Renewables 2016: Global Status Report. Paris: 2016.

[2] Carrasco LM, Martin-Campo FJ, Narvarte L, Ortuno MT, Vitoriano B. Design of maintenance structures for rural electrification with solar home systems. The case of the Moroccan program. Energy 2016;117:47-57. doi:10.1016/j.energy.2016.10.073.

[3] Yadoo A, Cruickshank H. The role for low carbon electrification technologies in poverty reduction and climate change strategies: A focus on renewable energy mini-grids with case studies in Nepal, Peru and Kenya. Energy Policy 2012;42:591-602. doi:10.1016/j.enpol.2011.12.029.

[4] IRENA. 2016 a Record Year for Renewables, Latest IRENA Data Reveals. Renew Energy Capacit Stat 2017 2017.

http://www.irena.org/News/Description.aspx?NType=A\&mnu=cat\&PriMenuID=16\&CatID=84\&News_ID=1 486 (accessed April 26, 2017).

[5] IRENA. Renewable capacity statistics 2016. Abu Dhabi: 2017.

[6] Lahimer AA, Alghoul MA, Yousif F, Razykov TM, Amin N, Sopian K. Research and development aspects on decentralized electrification options for rural household. Renew Sustain Energy Rev 2013;24. doi:10.1016/j.rser.2013.03.057.

[7] Hosseinalizadeh R, Rafiei E sadat, Alavijeh AS, Ghaderi SF. Economic analysis of small wind turbines in residential energy sector in Iran. Sustain Energy Technol Assessments 2017;20:58-71. doi:10.1016/j.seta.2017.02.018.

[8] Kaldellis JK, Kavadias KA, Koronakis PS. Comparing wind and photovoltaic stand-alone power systems used for the electrification of remote consumers. Renew Sustain Energy Rev 2007;11:57-77. doi:10.1016/j.rser.2004.12.001.

[9] Chaurey A, Kandpal TC. A techno-economic comparison of rural electrification based on solar home systems and PV microgrids. Energy Policy 2010;38:3118-29. doi:10.1016/j.enpol.2010.01.052.

[10] Nandi SK, Ghosh HR. Prospect of wind-PV-battery hybrid power system as an alternative to grid extension in Bangladesh. Energy 2010;35:3040-7. doi:10.1016/j.energy.2010.03.044.

[11] Schnitzer D. Microgrids for Rural Electrification : A critical review of best practices based on seven case studies Microgrids for Rural Electrification : A critical review of best practices. Berkeley: United Nations Foundation; 2014.

[12] Mathiesen BV, Lund H, Karlsson K. 100\% Renewable energy systems, climate mitigation and economic growth. Appl Energy 2011;88:488-501. doi:10.1016/j.apenergy.2010.03.001.

[13] Bekele G, Tadesse G. Feasibility study of small Hydro/PV/Wind hybrid system for off-grid rural electrification in Ethiopia. Appl Energy 2012;97:5-15. doi:10.1016/j.apenergy.2011.11.059.

[14] United Nations Development Programme. Towards an "Energy Plus" Approach for the Poor: An Agenda for Action for Asia and the Pacific. 2012.

[15] Terrapon-Pfaff J, Dienst C, König J, Ortiz W. A cross-sectional review: Impacts and sustainability of smallscale renewable energy projects in developing countries. Renew Sustain Energy Rev 2014;40:1-10. doi:10.1016/j.rser.2014.07.161.

[16] Brundtland GH. Our Common Future: Report of the World Commission on Environment and Development. Med Confl Surviv 1987;4:300. doi:10.1080/07488008808408783.

[17] Munasinghe M. Sustainable Development: Basic Concepts and Application to Energy. Encycl Energy 
2004;5:789-808. doi:10.1016/B0-12-176480-X/00441-1.

[18] Ilskog E. Indicators for assessment of rural electrification-An approach for the comparison of apples and pears. Energy Policy 2008;36:2665-73. doi:10.1016/j.enpol.2008.03.023.

[19] Yadoo A, Cruickshank H. The value of cooperatives in rural electrification. Energy Policy 2010;38:2941-7. doi:10.1016/j.enpol.2010.01.031.

[20] Schillebeeckx SJD, George G. An Integrated Framework for Rural Electrification : Adopting a User-Centric Approach to Business Model Development. Energy Policy 2012;48:687-97.

doi:http://dx.doi.org/10.1016/j.enpol.2012.05.078.

[21] López-González A, Domenech B, Gómez-Hernández D, Ferrer-Martí L. Renewable microgrid projects for autonomous small-scale electrification in Andean countries. Renew Sustain Energy Rev 2017;79:1255-65. doi:10.1016/j.rser.2017.05.203.

[22] MPPEE. Plan de Desarrollo del Sistema Electrico Nacional 2013-2019. Caracas: 2013.

[23] Instituto Nacional de Estadística. XIV Censo Poblacional de Población y Vivienda. Resultados por Entidad Federal y Municipio del Estado Falcón. Caracas: 2014.

[24] Instituto Nacional de Estadística. XIV Censo Poblacional de Población y Vivienda. Resultados por Entidad Federal y Municipio del Estado Zulia. Caracas: 2014.

[25] Instituto Nacional de Estadística. Censo 2011 Redatam 2017. http://www.redatam.ine.gob.ve/Censo2011/index.html (accessed March 24, 2017).

[26] Rubel F, Kottek M. Observed and projected climate shifts 1901-2100 depicted by world maps of the KöppenGeiger climate classification. Meteorol Zeitschrift 2010;19:135-41. doi:10.1127/0941-2948/2010/0430.

[27] Fundelec. Sembrando Luz: Promoviendo las Energías Renovables en Zonas Aisladas, Indígenas y Fronterizas del país 2012:32.

[28] Rojas-Zerpa JC, Yusta JM. Application of multicriteria decision methods for electric supply planning in rural and remote areas. Renew Sustain Energy Rev 2015;52:557-71. doi:10.1016/j.rser.2015.07.139.

[29] Pérez LA. The Guajira (Wayuu): Time, Space and Circumstances. Cuad Venez Sociol 2006;15:403-26.

[30] Sen R, Bhattacharyya SC. Off-grid electricity generation with renewable energy technologies inIndia: An application of HOMER. Renew Energy 2014;62:388-98. doi:10.1016/j.renene.2013.07.028.

[31] IRENA. Global Atlas Gallery 3.0 2017. https://irena.masdar.ac.ae/gallery/\#gallery (accessed June 19, 2017).

[32] National Renewable Energy Laboratory. NREL: Dynamic Maps, GIS Data, and Analysis Tools - Wind Data Details. Wind Energy Resour Atlas United States 2014. http://www.nrel.gov/gis/wind_detail.html?print (accessed March 16, 2017).

[33] Bautista S. A sustainable scenario for Venezuelan power generation sector in 2050 and its costs. Energy Policy 2012;44:331-40. doi:10.1016/j.enpol.2012.01.060.

[34] Instituto Nacional de Meteorología e Hidrología. Estadísticos Básicos de Precipitación, Temperatura y Humedad. Climatología 2017. http://www.inameh.gob.ve/web/climatologia/estadistica.php (accessed March 16, 2017).

[35] Cano L, Izquierdo O, Soria E, Cruz I. Curva de potencia del aerogenerador Bornay Inclin Neo 3000. Madrid: 2008.

[36] Rodríguez-Borges C, Sarmiento-Sera A. Competitiveness of the wind-photovoltaic hybrid systems for the rural electrification. Ing Mecánica 2015;18:12-22.

[37] De Pablos K. Solar and wind electricity sources. Alternative, clean and renewable energy. Orinoco Magna Reserv 2014:21-4.

[38] Xu Z, Nthontho M, Chowdhury S. Rural electrification implementation strategies through microgrid approach in South African context. Int J Electr Power Energy Syst 2016;82:452-65. doi:10.1016/j.ijepes.2016.03.037.

[39] Baneshi M, Hadianfard F. Techno-economic feasibility of hybrid diesel/PV/wind/battery electricity generation systems for non-residential large electricity consumers under southern Iran climate conditions. Energy Convers Manag 2016;127:233-44. doi:10.1016/j.enconman.2016.09.008.

[40] Nehrir MH, Wang C, Strunz K, Aki H, Ramakumar R, Bing J, et al. A Review of Hybrid Renewable / Alternative Energy Systems for Electric Power Generation: Configurations, Control, and Applications. IEEE Trans Sustain Energy 2011;2:392-403. doi:10.1109/TSTE.2011.2157540.

[41] Zahboune H, Zouggar S, Krajacic G, Varbanov PS, Elhafyani M, Ziani E. Optimal hybrid renewable energy design in autonomous system using Modified Electric System Cascade Analysis and Homer software. Energy Convers Manag 2016;126:909-22. doi:10.1016/j.enconman.2016.08.061.

[42] Kattakayam TA, Srinivasan K. Lead acid batteries in solar refrigeration systems. Renew Energy 2004;29:1243-50. doi:10.1016/j.renene.2003.12.019.

[43] Yang H, Wei Z, Chengzhi L. Optimal design and techno-economic analysis of a hybrid solar-wind power generation system. Appl Energy 2009;86:163-9. doi:10.1016/j.apenergy.2008.03.008.

[44] IDAE. Pliego de Condiciones Técnicas de Instalaciones Aisladas de Red. Instituto para la Diversificación y Ahorro de la Energía; 2009.

[45] Kellogg WD, Nehrir MH, Venkataramanan G, Gerez V. Generation unit sizing and cost analysis for standalone wind, photovoltaic, and hybrid wind/PV systems. IEEE Trans Energy Convers 1998;13:70-5. doi:10.1109/60.658206.

[46] Lotfi H, Khodaei A. Static hybrid AC/DC microgrid planning. 2016 IEEE Power Energy Soc Innov Smart 
Grid Technol Conf 2016:1-5. doi:10.1109/ISGT.2016.7781274.

[47] Karabiber A, Keles C, Kaygusuz A, Alagoz BB. An approach for the integration of renewable distributed generation in hybrid DC/AC microgrids. Renew Energy 2013;52:251-9. doi:10.1016/j.renene.2012.10.041.

[48] Rodriguez-Borges C. Valoración integral de sistemas híbridos para la electrificación rural. Instituto Superior Politécnico "José Antonio Echeverría," 2011.

[49] Liu W, Wang C, Mol APJ. Rural public acceptance of renewable energy deployment: The case of Shandong in China. Appl Energy 2013;102:1187-96. doi:10.1016/j.apenergy.2012.06.057.

[50] Urmee T, Md A. Social, cultural and political dimensions of off-grid renewable energy programs in developing countries. Renew Energy 2016;93:159-67. doi:10.1016/j.renene.2016.02.040.

[51] Lillo P, Ferrer-Martí L, Fernández-Baldor Á, Ramírez B. A new integral management model and evaluation method to enhance sustainability of renewable energy projects for energy and sanitation services. Energy Sustain Dev 2015;29:1-12. doi:10.1016/j.esd.2015.08.003.

[52] Lillo P, Ferrer-Martí L, Boni A, Fernández-Baldor Á. Assessing management models for off-grid renewable energy electrification projects using the Human Development approach: Case study in Peru. Energy Sustain Dev 2015;25:17-26. doi:10.1016/j.esd.2014.11.003.

[53] Hongzhou Wang HP. Reliability and Optimal Maintenance. 2006. doi:10.1073/pnas.0703993104.

[54] Vera I, Langlois L. Energy indicators for sustainable development. Energy 2007;32:875-82. doi:10.1016/j.energy.2006.08.006.

[55] Brent AC, Rogers DE. Renewable rural electrification: Sustainability assessment of mini-hybrid off-grid technological systems in the African context. Renew Energy 2010;35:257-65. doi:10.1016/j.renene.2009.03.028.

[56] Pachauri S. Reaching an international consensus on defining modern energy access. Curr Opin Environ Sustain 2011;3:235-40. doi:10.1016/j.cosust.2011.07.005.

[57] United Nations. Transforming our world: The 2030 agenda for sustainable development. 2015. doi:10.1007/s13398-014-0173-7.2.

[58] Cader C, Blechinger P, Bertheau P. Electrification Planning with Focus on Hybrid Mini-grids - A Comprehensive Modelling Approach for the Global South. Energy Procedia 2016;99:269-76. doi:10.1016/j.egypro.2016.10.116.

[59] Ilskog E, Kjellström B. And then they lived sustainably ever after?-Assessment of rural electrification cases by means of indicators. Energy Policy 2008;36:2674-84. doi:10.1016/j.enpol.2008.03.022.

[60] Schuessler R. Energy Poverty Indicators: Conceptual Issues - Part I: The Energy Poverty Indicators TenPercent-Rule and Double Median / Mean Indicators. vol. 14-037. Bayreuth: 2014. doi:10.2139/ssrn.2459404.

[61] Hills J. Getting the measure of fuel poverty: Final Report of the Fuel Poverty Review. Centre for Analysis of Social Exclusion, London School of Economics and Political Science; 2012.

[62] Moore R. Definitions of fuel poverty: Implications for policy. Energy Policy 2012;49:19-26.

[63] Boardman B. Fuel poverty: from cold homes to affordable warmth. Pinter Pub Limited; 1991.

[64] Boardman B. Fixing fuel poverty: challenges and solutions. Routledge; 2013.

[65] Regnault B. Asistencia y permanencia escolar de la niñez y adolescencia indígena en Venezuela. Caracas: 2006.

[66] FDA. Fish and Fishery Products Hazards and Controls Guidance. Fish Fish Prod Hazard Control Guid Fourth Ed 2011:1-401. doi:10.1039/9781847558398-00136.

[67] Rodríguez de Sifontes Y, Betancourt K. Análisis de la situación sobre la práctica de lactancia materna en Venezuela. Caracas: Fondo de las Naciones Unidas para la Infancia-UNICEF Venezuela; 2015.

[68] Lam NL, Smith KR, Gauthier A, Bates MN. Kerosene: a review of household uses and their hazards in lowand middle-income countries. J Toxicol Environ Health B Crit Rev 2012;15:396-432. doi:10.1080/10937404.2012.710134.

[69] Azimoh CL, Klintenberg P, Wallin F, Karlsson B. Illuminated but not electrified: An assessment of the impact of Solar Home System on rural households in South Africa. Appl Energy 2015;155. doi:10.1016/j.apenergy.2015.05.120.

[70] Fernández-Bujanda L, Torres W, Urdaneta L, Vargas J. Distribución del ingreso en Venezuela. Caracas: 2008.

[71] World Bank. Poverty and Shared Prosperity 2016. Washington, DC: 2016. doi:10.1596/978-1-4648-0958-3.

[72] Domínguez L. Evaluaciones económicas y ajustes de precios a contratos de PDVSA: Refinería El Palito. Bárbula: 2014. 